
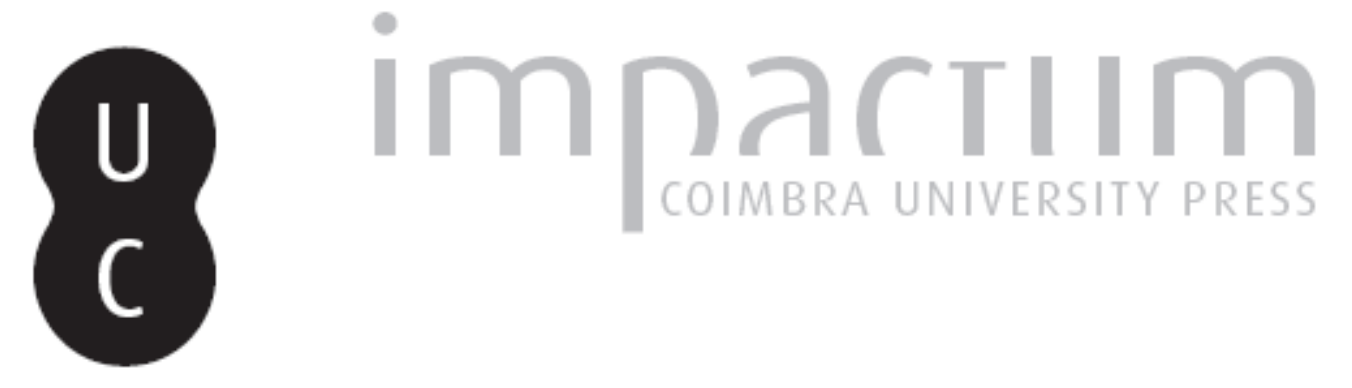

\title{
O elogio fúnebre de Afonso de Albuquerque de Frei Sebastião Toscano
}

Autor(es): $\quad$ Marques, Armando de Jesus

Publicado por: Imprensa da Universidade de Coimbra

URL persistente:

URI:http://hdl.handle.net/10316.2/43932

DOI:

DOl:https://doi.org/10.14195/2183-8925_3_8

Accessed : $\quad$ 26-Apr-2023 15:58:38

A navegação consulta e descarregamento dos títulos inseridos nas Bibliotecas Digitais UC Digitalis, UC Pombalina e UC Impactum, pressupõem a aceitação plena e sem reservas dos Termos e Condições de Uso destas Bibliotecas Digitais, disponíveis em https://digitalis.uc.pt/pt-pt/termos.

Conforme exposto nos referidos Termos e Condições de Uso, o descarregamento de títulos de acesso restrito requer uma licença válida de autorização devendo o utilizador aceder ao(s) documento(s) a partir de um endereço de IP da instituição detentora da supramencionada licença.

Ao utilizador é apenas permitido o descarregamento para uso pessoal, pelo que o emprego do(s) título(s) descarregado(s) para outro fim, designadamente comercial, carece de autorização do respetivo autor ou editor da obra.

Na medida em que todas as obras da UC Digitalis se encontram protegidas pelo Código do Direito de Autor e Direitos Conexos e demais legislação aplicável, toda a cópia, parcial ou total, deste documento, nos casos em que é legalmente admitida, deverá conter ou fazer-se acompanhar por este aviso.

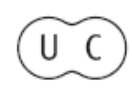




\section{REVISTA DE HISTORIA DAS IDEIAS}

Volume III

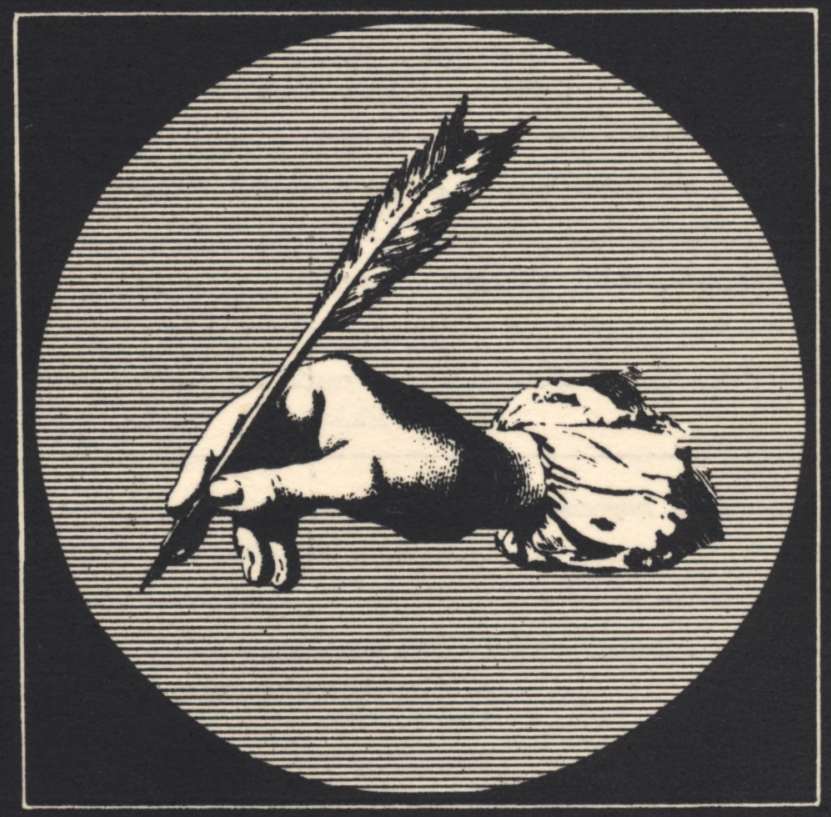

INSTITUTO DE HISTÓRIA E TEORIA DAS IDEIAS

$$
\begin{gathered}
\text { FACULDADE DE LETRAS } \\
\text { COIMBRA } 1981
\end{gathered}
$$




\section{O ELOGIO FÚNEBRE DE AFONSO DE ALBUQUERQUE DE FREI SEBASTIÃO TOSCANO}

Afonso de Albuquerque deixara em testamento que o seu corpo fosse depositado na capela de Nossa Senhora da Conceição, em Goa; mas que dali trouxessem depois seus ossos a Portugal e os enterrassem em Santa Maria da Graça, de Lisboa. Essa trasladação realizou-se a 19 de Maio de 1566. Na respectiva cerimónia pregou Frei Sebastião Toscano a Orą̧ão que ora se publica.

Apresentar a figura histórica de Afonso de Albuquerque seria supérfluo e alheio ao nosso propósito. Não será, porém, descabido antepor a esta publicação algumas palavras tanto acerca do orador que proferiu este elogio fúnebre do grande capitão, como a respeito da peça oratória propriamente dita.

Sebastião Toscano passou quase despercebido até ao presente, embora seja um personagem de certo relevo na história religiosa europeia do seu tempo. Natural do Porto, estudante em Salamanca e Bolonha, secretário e amigo do famoso Seripando, pregador e áulico de D. João III, encarregado de uma espinhosa missão diplomática na Inglaterra, chegou - por duas vezes - a provincial dos Agostinhos, a Ordem em que professara quando estudava Leis na Universidade de Salamanca. E eis aqui, num breve bosquejo, a trajectória da sua vida apaixonante.

Relativamente ao seu espólio literário (pois é um dos bons prosadores daquele tempo), lembremos além desta Oração fúnebre de Afonso de Albuquerque (Lisboa, 1566), a Mistica Teologia (Lisboa, 1568) e os Commentarii in Jonam Prophetam (Veneza, 1573). Isto para não falar quer do seu Epistolário (cerca de quinze cartas inéditas que esperamos dar à estampa), quer da sua tradução castelhana das Confissões 
de Santo Agostinho (a primeira na língua de Cervantes e que correu mundo naquele século espanhol) (1).

Feito assim este breve resumo da sua vida e da sua projecção no campo da nossa cultura quinhentista, debrucemo-nos então sobre o texto agora reeditado (2). Não pretendemos escrever uma introdução propriamente dita -- introdução que reservamos para a edição das Opera Omnia de Mestre Sebastião Toscano. Vamos anotar somente o que de momento se nos afigura de particular interesse. Apontaremos, primeiro, algumas singularidades deste elogio fúnebre como peça oratória; sublinharemos, depois, alguns reflexos que nestas páginas se podem vislumbrar da cultura humanístico-teológica do seu autor.

(1) Os interessados podem colher mais amplos dados biográfico-doutrinais nos seguintes trabalhos: Armando de Jesus Marques, Os Reimões do Porto e Riba-Douro no século XVI. Sep. do «Boletim Internacional de Bibliografia Luso-Brasileira", vol. III. Lisboa (Fundação Calouste Gulbenkian), 1962. — Frei Sebastião Toscano na conjuntura religiosa da sua época. Sep. da «Revista Portuguesa de História", t. VII. Coimbra (Faculdade de Letras da Universidade), 1963.

No primeiro estudo, moveu-nos um duplo objectivo: a) reconstituir o quadro familiar de Sebastião Toscano, lançando um pouco de luz sobre os anos da sua infância e da sua primeira educação; b) estabelecer, com base em documentação irrefragável de arquivo, a sua ascendência lidimamente portuguesa, posta em dúvida por certo autor espanhol.

No segundo estudo, dispusemos, por ordem cronológica, os documentos que em torno da sua vida pudemos recolher - o que nos deu uma primeira antevisão da respectiva biografia e serviu de fio condutor da narração quando, mais tarde, elaborámos a nossa tese de doutoramento sobre a sua vida e a sua obra.

Desta tese, ainda por publicar, podem consultar-se dois resumos: Frater Sebastianus Toscanus, O.S.A. - spiritualis doctrinae auctor Lusitanus saeculi XVI. Sep. de «Helmantica-Revista de Humanidades Clásicas de la Universidad Pontificia de Salamanca", n. ${ }^{\circ}$ 49. Salamanca, $1965 ;-D a$ vida e escritos do humanista português Frei Sebastião Toscano. Sep. de «Portugiesische Forschungen der Görresgesellschaft. Erste Reihe - Aufsätze zur portugiesischen Kulturgeschichte», vol. VI. Münster Westfalen, 1966.

(2) Como atrás se viu, não se trata efectivamente de um texto inédito: foi impresso no ano de 1566, em Lisboa, nas oficinas de Manuel João. Mas nunca mais viu a luz da publicidade. Inocêncio diz mesmo a seu respeito: «é um dos livros mais raros da nossa literatura, e do qual não pude ver até agora algum exemplar» (Dicionário..., t. VII, Lisboa 1862, p. 224). Felizmente, conhecem-se agora dois espécimes: o que se guarda no Arq. Nac. da Torre do Tombo (Impressos, Série Preta, 14112) e o da Bibl. Pública de Évora (Séc. XVI, 2728). 


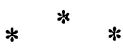

A primeira singularidade da Oração encontramo-la logo no exórdio. Há-de este - dizem os tratadistas clássicos - conciliar a atenção e benevolência dos ouvintes, e pô-los ao corrente do que se vai dizer. Ora, o exórdio da Oração é excessivamente breve (embora se apresente emoldurado num texto de Píndaro) e só realiza um dos fins assinalados para esta primeira parte do discurso. $\mathrm{Na}$ verdade, tudo se resume nisto: - Para enaltecer os méritos de Afonso de Albuquerque, preciso da graça de Deus e da vossa: peçamo-la: Avé Maria!

Temos de convir que é pouco. Reparemos, todavia, que outros oradores célebres patenteiam-de quando em quando-idêntica imperfeição. É o caso de Vieira (3). É o caso de Mendoza, num sermão de Nossa Senhora, cujo exórdio vamos mesmo transcrever, para melhor documentar a asserção:

«Exsurgens autem Maria abiit in montana cum festinatione in civitatem Juda. Lucas, $I$.

Estamos em casa real de misericórdia. A Senhora da casa, que é a Virgem Sacratíssima, ou Mãe de misericórdia. Os vassalos, que é esta mesa, e irmandade tão nobre; misericordiosos irmãos, da misericórdia. Tudo aqui é misericórdia. Porque tudo se resolve em Mãe de misericórdia: e irmãos, ou filhos de misericórdia. Desta havemos de tratar em dous discursos. No primeiro tratarei da misericórdia da Mãe. No segundo da misericórdia dos filhos. Tudo acharemos no Evangelho: é matéria larga: mas a calma pede pregação breve. Forremos tempo e peçamos a graça» (4).

Aqui está, dizíamos, um exórdio demasiado breve (e sem miga de originalidade!), apesar dos reconhecidos dotes oratórios de quem o

(3) Cf. Sermão da Ressurreição de Cristo Senhor Nosso, ed. de Lello \& Chardron, vol. V, Porto 1907, p. 125.

(4) Cf. Segunda Parte dos Sermões do Padre Francisco de Mendoça, da Companhia de Jesus, Doutor na Sagrada Teologia, Lente que foi de Escritura na Universidade de Évora... Em Lisboa. Na Oficina de Lourenço de Anveres e à sua custa. Ano de 1649, pp. 61-62. Foi pregado em Coimbra, na Santa Casa da Misericórdia, festa da Visitação, aos 2 de Julho de 1620. 
proferiu. Cremos que valeu a pena trasladá-lo. E não apenas por sairmos, de algum modo, em defesa da nossa dama, mas ainda para notar uma curiosa coincidência.

Já quase a rematar o exórdio, diz Francisco de Mendoza que a matéria é larga, «mas a calma pede pregação breve». Pois também Sebastião Toscano afirma em certo passo da Oração que muito haveria a contar do Terribil, mas o não fará "porque o tempo é pouco e muita a calma» (5). E eis como na parenética de Quinhentos e Seiscentos o calor servia de pretexto para resolver situaç̃es delicadas...

O autor entra depois no corpo do discurso. Dispamos este dos seus ornamentos e prescindamos de algumas redundâncias, tentando apanhar o cerne da argumentação.

Hão-de louvar-se os varões ilustres a fim de que os seus descendentes se esforcem, depois, por imitá-los. E quais são eles? - Os justos: In memoria aeterna erit iustus. Ora os justos são os que possuiram a bondade. E visto que só as virtudes fundamentam solidamente a bondade humana, a estas devemos sobretudo louvar.

Feita a transposição, o orador inicia um longo arrazoado sobre as virtudes: primeiro, as três virtudes teologais; depois, as quatro cardeais. Nestas, é de frisar como alterou a sua ordem tradicional (prudência, justiça, fortaleza e temperança).

Em seguida, reverte ao assunto: «Pois sabemos donde nace a glória e honra, cuja é, e a quem se deve dar, louvemos - como diz o filho de Sirach - os barões gloriosos, que são os virtuosos». Somente, Portugal tem tido muitos... "Deixados os outros pera seus tempos», atenhamo-nos agora a Afonso de Albuquerque. E começa a evocação da figura do grande Governador perante os despojos mortais ali presentes sobre o catafalco.

Com rara felicidade, lança mão para tal da figura literária da preterição: nada dirá das forças da sua espada, da prudência no governo e no trato das coisas da guerra, de seus bem afortunados cometimentos, de seus bravos assaltos contra os inimigos, de seus prósperos sucessos, da fé e lealdade a seu rei, de seus muitos e grandes serviços, dos duros trabalhos da guerra, dos perigos do mar, dos enfadamentos da terra, do sofrimento da gente desmandada que - como tempestade e tor-

(5) Oração, f. 19. 
menta desfeita - às vezes se alevanta, quando o furor lhe dá, e ministra novas e não cuida das armas; nem menos dirá quão fácil era a todos, quão temido dos inimigos, dos amigos quão amado, quão vitorioso nas batalhas; tão pouco dirá quão presto era no obrar (depois de maduro e vagaroso conselho), quão misericordioso com os pupilos e viúvas, quão largo nas mercês, quão honesto em seu falar... Nada disto dirá. A razão é que nunca foi seu intento louvar forças do corpo que se acaba, mas forças do ânimo e virtude.

O leitor, sacudido por este frémito quase de epopeia, fica a seguir um tanto desalentado. A figura do professor, geométrico, didáctico, que já se afiançara ao tratar das virtudes, volta a emergir. Atrás, embrenhara-se em Aristóteles, em Averróis, em Pedro Lombardo, em exemplos do Velho Testamento; agora, envereda por etimologias fantasiosas e tradições talvez lendárias ao debuxar a genealogia de Afonso de Albuquerque. Era preciso contentar os parentes que assistiam...

Fala também de três reis de quem descende, de três reis a quem serviu, de três reis a quem venceu. Diz ainda de três insignes capitães aos quais se assemelhou e de três importantes fortalezas que fundou. Como se isto não bastasse, evoca as quatro virtudes cardeais, em que foi «tão estremado", para - somando três com quatro - lhe chamar três vezes grandíssimo e sete vezes bem-aventurado...

Como em nota se explica, temos de abstrair das nossas concepç⿸丆es actuais e mergulhar no mundo medievo antes de pensarmos que $o$ autor se deixou arrastar por um especioso jogo de números. Reparemos antes em como estes e outros elementos antigos se casavam com os novos e eram aceites, por um público selecto, em plena época humanista.

O encadeamento lógico nem sempre surge claramente e limpo de interpolaçð̃es um tanto ou quanto forçadas. Por essa razão, a fronteira entre o corpo do discurso e a anacefaleose não se apresenta bem definida. No entanto, há uma recapitulação em que menciona de novo algumas virtudes já apontadas e sublinha alguns traços mais salientes: pagar o mal com o bem; reger com justiça inflexível; ser munificente; confiar em Deus...

$\mathrm{Na}$ conclusão, evoca os últimos dias e as últimas disposiçð̃es de Afonso de Albuquerque e faz uma referência ao filho ali presente, abrindo, numa peroração brilhante, a perspectiva da ressurreição final e da futura bem-aventurança. 
$O$ estilo é o homem. Por consequência, detenhamo-nos agora nalgumas passagens da Oração que reflitam melhor a personalidade de Sebastião Toscano, quer como humanista, quer como teólogo-professor.

Jerónimo Seripando, então Geral dos Agostinhos, veio em 1541 a Portugal de visita aos mosteiros da sua Ordem. Agradou-se de Frei Sebastião Toscano e levou-o no seu séquito para a Itália (6). $\mathrm{O}$ antigo escolar de Leis em Salamanca fez assim uma viagem aliciante, através dos Pirenéus e dos Alpes, de convento em convento, até chegar a Roma. De resto, Seripando nomeou-o seu secretário, ainda no caminho (7), e isso deu lugar a que tomasse contacto, na Cidade Eterna, com gente sabedora e de influência ( $\left.{ }^{8}\right)$.

(6) «Levou consigo a frei Sebastião Toscano de quem dizia que todo era entendimento». Bibl. Nac. de Lisboa, F.G., Res. 645, f. 143v.

(7) Foi em Milão a 6-III-1542. Sucedeu no cargo de "scriptor Ordinis» a Frei Marcos Tarvisino. Arch. Ordinis, $D d$ 19, f. 125v.

Designamos por Arch. Ordinis o arquivo generalício agostiniano, de Roma. O códice $D d 19$ até $D d 24$ são os registos do Prior Geral, Seripando. O códice Aa 48, citado a seguir, intitula-se «Notitiae Provinciae Lusitaniae» e é constituído, como o próprio nome indica, pelas cartas e outros informes enviados pela Província de Portugal.

(8) Além de Seripando, Toscano teve em Roma relações de amizade com o Cardeal de Burgos, o Cardeal Capodiferro e Pedro António de Cápua, bispo de Otranto. É o que se colige do bilhete que acompanhou, em 1545, alguns presentes que ele enviou de Portugal aos seus amigos de Itália.

O bilhete ia dirigido a Jerónimo Seripando. Após especificar o que era destinado ao seu querido Superior, Toscano acrescenta: «De las otras tres bocetas, la una mandará Vuestra Paternidad Reverendísima dar a monseñor de Burgos, que lleva su nombre scrito; la otra, a monseñor de Ottrento, Pietro Antonio de Capua; la tercera, al padre fray Juan Baptista (...). La nave que esto lleva parte de esta ciudad de Lixboa a xx de este mes de Octubre, y va a Livorno y a Civitavecchia, y lleva mercaduría con muesos (!) presentes a esa ciudad, scilicet, a monseñor Caput de Ferro y a otros señores». Arch. Ordinis, $A a$ 48, f. 311-311v.

Aquele «Monsenhor de Burgos» é D. João Álvares de Toledo, tio do duque de Alba e irmão do vice-rei de Nápoles. Nasceu em 1488; tomou o hábito de São Domingos; e, preconizado em 1537 arcebispo de Burgos, foi feito cardeal em 1538 continuando como "Cardinalis Burgensis» ou «Monsenhor de Burgos» até 1550, ano em que foi trasladado para Compostela. Foi personagem de grande aceitação e bom nome na Cúria Romana até ao ano de 1557, o da sua morte. Cf. Luís PASTOR, Storia dei Papi, vols. V-VI-VII-VIII, Roma 1931-27-28-29.

«Monsenhor de Ottrento» (está mal escrito assim!) era Pedro António de Cápua, arcebispo de Otranto - porto da Itália meridional, voltado para o mar Egeu 
Como não se afez ao clima de Roma, a sua peregrinação por Itália continuaria: estudou e bacharelou-se em Bolonha (9); foi, depois, Regente de Estudos em Nápoles (10), até que, em 1545, regressou a Portugal, já Mestre em Teologia (11).

— desde 1536 a 1579. Foi figura de certo relevo no Concílio de Trento. Cf. PASTOR, vols. cits.

«Monsenhor Caput de ferro» foi personagem de grande importância na Cúria Romana durante o pontificado de Paulo III. Chamava-se Jerónimo Capodiferro e morava num formoso palácio, nas vizinhanças de «Ponte Sisto», o qual foi levantado à volta de 1540 e decorado por Júlio Mazzoni, discípulo de Daniel de Volterra. O curriculum vitae de Capodiferro pode resumir-se assim: foi mandado como núncio a Portugal em 1537; depois, transferiram-no para a França, donde só voltaria em 1543; recebeu o chapéu cardinalício em 1544; e foi um dos delegados para a paz que, em 1553, Paulo III pretendia instaurar entre franceses e imperiais. Morreu em 1559. Cf. Pastor, vol. VII.

Evidentemente, não se limitaram a estas três figuras de que temos documentos os contactos de Frei Sebastião Toscano em Roma. Secretário do Geral, teve oportunidade de conhecer muitas outras, na Cúria e no século. Além de que por lá andavam também D. Teotónio de Bragança, Francisco de.Holanda, Cristóvão Falcão, Afonso Vaz da Costa, Francisco Galvão, Damião de Góis, D. Manuel de Portugal, etc..

(9) No capítulo geral celebrado em Roma de 11 a 16-V-1543. Seripando foi confirmado no cargo de Geral. No fim do capítulo, designou o pessoal dos Estudos Gerais. Sebastião Toscano ficou em Bolonha. O seu nome está ligado com os de outros três religiosos por uma linha vertical. Têm à margem esta nota, escrita por ordem de Seripando: «quos baccalaureos creamus». Arch. Ordinis, Dd 20, f. 70.

(10) «Institutus est regens in congregatione Sancti Ioannis ad Carbonariam venerabilis baccalaureus frater Sebastianus Toscanus, Lusitanus». Arch. Ordinis, Dd 20, f. 97. É Seripando quem o faz Regente de Estudos na dita congregação, que tinha os seus conventos em Nápoles e arredores. "Venerabilis» é o mesmo que «Reverendus».

(11) Seripando: "Venerabilem baccalaureum fratrem Sebastianum Toscanum magistrum in sacra theologia fecimus auctoritate apostolica. Cui aliis litteris concessimus ducatos aureos XL, ex quacumque haereditate quae Salmantino conventui sui causa posset contingere; et hoc ad expensas sibi necessarias in Hispaniam ex Italia proficiscenti. Quam pecuniam voluimus Patres Salmanticensis conventus in partem dictae haereditatis a matre eiusdem Sebastiani recipi, vel a quibuscumque talis haereditas conventui praedicto traderetur».

E acrescenta: «Certiores redditi in maximam spem litterarum nostram religionem Portugalliae, quae olim litterarum studio carebat, sublatam esse diebus nostris serenissimi Regis ope et Montoyae ac Villafrancae - vicariorum nostrorum industria, volentes eorum labores iuvare, praefatum magistrum Sebastianum illis misimus, litteris, fide et moribus probatum».

Arch. Ordinis, $D d 21$, ff. 62v-63. 
Mas as suas andanças não ficaram por aqui. Em 1556 partiu para Inglaterra numa tentativa de recuperar os conventos ingleses em face da esperança que representava para o Catolicismo o matrimónio de Filipe II com Maria Tudor. E embora não tenha conseguido alcançar o termo da viagem, chegou ao menos até Bruxelas, onde foi recebido pelo Rei Prudente e provou o sortilégio espiritual da apaixonante Flandres daquele tempo (12).

E mais se podia ainda dizer das suas viagens pelo largo mundo. Não vale a pena. O quadro ora debuxado já basta para o nosso propósito: entender na sua verdadeira dimensão a passagem do elogio fúnebre em que Sebastião Toscano se refere ao epitáfio de Pico della Mirandola, citando-o textualmente e acomodando-o a Afonso de Albuquerque. Com efeito, pudera tê-lo aduzido sem mais. Mas não. Num jeito muito humanista, faz notar que esteve lá, que o viu pessoalmente: «... alembrei-me de um epitáfio de Pico Mirandulano, que li na cidade de Florência (que é em Itália, no reino de Toscana), que diz assi: ...».

Outro rasto da mundividência humanista de Sebastião Toscano se descobre na Oração: as frequentes citações clássicas. Virgílio aparece quatro vezes, em trechos extraídos da Eneida. Horácio vem à colação igualmente quatro vezes: primeiro, em três passagens mais ou menos referenciadas das Odes; e, quase no fim, reaparece ainda, encapotadamente, num breve inciso das Sátiras.

Ao grande épico e ao grande lírico da literatura latina vêm somar-se os seus homólogos da epopeia e do lirismo gregos: Homero e Píndaro. Este último figura logo no exórdio da Oração, conforme já dissemos. E é de assinalar o esforço concordista de que Sebastião Toscano aí faz prova (e que desenvolverá noutras passagens das suas obras). Homero é recordado no livro segundo da Ilíada, para documentar o asserto de que «na polícia bem ordenada, não há-de haver muitos que mandem, mas um só rei, um só senhor e governador, e esse posto da mão de Deus».

(12) Sebastião Toscano ao novo Geral, Cristóvão de Pádua: «Per id temporis in Angliam missus a Paternitate Tua Reverendissima vicarius, acceptis litteris a serenissimo Rege nostro ad regem Philippum et Mariam Angliae reginam - in quibus me magnopere commendabant - Brusellas veni ubi a rege Philippo honorifice susceptus, quanta potuit rex diligentia nunquam effecit ut additum in Angliae regnum invenirem». Arch. Ordinis, $A a$ 48, f. 354. 
Estas citações de Homero e Píndaro merecem que sobre elas teçamos ainda um breve comentário. De feito, o texto da Oração exibe-as na própria língua original. Não nos atrevemos a dizer que seja um facto inédito, mas há-de ser ao menos bastante raro. Por nós, desconhecemos outro exemplo de sermão em que tal aconteça. E por isso pode-se perguntar: estas duas passagens gregas foram declamadas no púlpito mesmo assim, ou só foram postas na língua original quando se imprimiu o sermão?

Enfim, aos quatro grandes vultos do mundo clássico acabados de mencionar juntemos alguns mais, já estrelas de segunda grandeza, mas que compõem o séquito: Énio, Plutarco, para não falar das alusões humanistas a Hermes Trismegisto, a Eustátio, aos ripsáspidas, etc.

Antes de fechar este capítulo, digamos uma palavra sobre as adaptaçðes (mais ou menos rigorosas, mais ou menos acomodatícias), por que passaram algumas citaçðes poéticas. Iremos mostrando em nota até que ponto Sebastião Toscano conseguiu ou não salvar o rigor da métrica. Mas adiantemos desde já que nos moveu, ao realizar este trabalho, um mero conato de dilucidação crítica. Como a seu tempo voltaremos a lembrá-lo, a falta de rigor - onde a notarmos - nem desdoura Frei Sebastião Toscano, nem este decerto a pretendeu.

Vejamos, finalmente, como se projecta no elogio fúnebre a personalidade de Sebastião Toscano enquanto teólogo-professor.

Um primeiro exemplo, bem típico, é o estreme método dedutivo, perfeitamente escolástico, de que lança mão para falar das pessoas virtuosas, em que quer catalogar a Afonso de Albuquerque.

Com Pedro Lombardo, diz que «hai três géneros de bens: uns grandes, e outros pequenos, e outros meãos». Os bens grandes são as virtudes; os pequenos, os dotes corporais; os meãos, as potências da alma. Socorre-se de Aristóteles para demonstrar que, destes últimos, não nos pode advir honra, nem menos vitupério; serve-se de algumas imagens para concluir que também de riquezas e contentamentos pessoais mal podemos gloriar-nos. Restam, pois, as virtudes, ou forças, ou poderes, «porque podem fazer (e de feito fazem), aos que as posseem, grandes e poderosos». Só estas merecem louvor.

Depois, vai expondo por sua ordem as virtudes teologais, no que gasta quase três páginas. Perfeito espírito didáctico: bastos exemplos da Escritura abonam a argumentação; uma que outra figura literária alivia o discurso e ajuda a agarrar a ideia. 
Simplesmente, posto que estas três virtudes teologais «são as que principalmente dão ao homem honra e glória, nem por isso se devem defraudar as virtudes morais da sua glória e valia». E lá cita (seguindo, como já dissemos, uma enumeração diferente da tradicional) as quatro virtudes cardeais. Aqui é mais breve. Remata até com uma bela metáfora em que junta o simbolismo bíblico do ouro de Evilath ao sortilégio do Oriente, donde nos vinham as especiarias e as pérolas.

O professor volta, porém, a dissertar: «Pois sabemos donde nace a glória, cuja é, e a quem se deve dar, louvemos - como diz o filho de Sirach - os barões gloriosos, que são os virtuosos». Mas Portugal teve e tem muitos... Atenhamo-nos, pois (e por agora), a Afonso de Albuquerque... E lá entra, finalmente, no assunto.

O teólogo-professor emerge ainda noutros passos do elogio fúnebre, mas só citaremos mais um: aquele em que descreve a morte de Albuquerque. Fá-lo, tecendo primeiro algumas considerações de ordem ascética. Mas o seu pensamento escatológico irrompe, incontido, nos períodos finais. Ora resumamos a passagem em questão.

Com dois amigos, o confessor e o testamenteiro, «steve toda a noite departindo. Não como quem morria. Mas mui quieto e descansado, como quem parte de um reino a outro, despondo de sua casa e bens. Qual é a morte dos justos, como foi a do patriarca Jacob (...) que, stando pera se partir desta vida, lançou a bênção a seus filhos, profetizando o que deles havia de ser, e lhes encomendou que o enterrassem e levassem a sua terra a descansar na morte, pois não descansara na vida, dizendo - Eu me vou ajuntar a meu povo».

A este propósito - continua - muitas e grandes cousas havia aqui que contar, que cala pela brevidade do tempo. Mas ao menos de três desejava não fossem esquecidos.

A primeira é que usendo tanto sem cuidado os santos de casas grandes e ricos paços, contentes com ũas pequenas, pobres e frias cabanas ou tendas, (...) eram mui cuidadosos das sepulturas. E pera isto compravam campos em que as faziam e lavravam, mui solícitos da ossada os que a carne pisaram e acoucearam». O orador agostiniano explica, depois, que os santos procediam assim pela sua fé na ressurreição, que os levava a preparar os túmulos «como arcas de depósito em que guardavam as tais relíquias que haviam ainda de ter honra perpétua, como gente que tinha seu nome scripto no Livro da Vida».

Uma segunda coisa se deve considerar: «é ver como morrem os santos pacífica e quietamente, falando, partindo-se e despondo de 
suas cousas, não como quem morre, mas como quem vai de ũa terra a outra pera tornar a ver os seus».

Por fim, lá vem - eclético e um tanto nebuloso - o seu pensamento teológico em matéria de Novíssimos: «O terceiro que pedem estas palavras do patriarca é ver que povo é este pera onde partiram os santos passados, pois não era o paraíso terreal, que ainda não estava aberta a porta do Céu. Serem ajuntados os santos daquele tempo a seu povo, há-se entender quanto à alma, pois isto se fazia antes de enterrar o corpo. Alguns doutores dizem que este povo dos santos antigos era o ajuntamento ou a frequência dos anjos. Outros dizem que era o Limbo, onde os santos padres estavam».

Afloremos, já agora, mais uma questão: o autêntico arsenal escrituristico que ao longo da Oração se estadeia. A tal respeito, caberia perguntar em que medida corresponde a uma verdadeira formação biblista ou é de raiz litúrgica - eco da recitação do ofício diário no coro. O fenómeno repete-se, porém, nas restantes obras de Sebastião Toscano, recebendo mais adequado tratamento na edição crítica de todas elas que atrás se promete.

Rematemos. Mas não se tire do que levamos dito a seguinte conclusão: pelos vistos, o elogio fúnebre vale pouco como peça oratória, embora valha bastante como reflexo de uma vida e de uma cultura. Tal ilacção seria uma ilacção errada. O leitor verá como sobejam ao longo do discurso modos de dizer, figuras do estilo e trechos de antologia que entremeiam a aridez de alguns temas e, na sua rara delicadeza, quase no-los fazem esquecer. Nem se perca de vista que, mesmo nos assuntos mais áridos, temos diante de nós a letra mumificada de um discurso: falta-lhe toda a vida que lhe emprestou - em calor humano, em requintada expressividade - «um dos mores pregadores do seu tempo» (13). É este um elogio singular que um historiador, seu coetâ-

(13) Bibl. Geral Univ. Coimbra, ms. 436, f. 30. É um volume in folio, sem título, mas, no verso da primeira folha, alguém escreveu: «Acaso será este livro (ou sua cópia?) escripto por D. Frei Aleixo de Menezes, mencionado na Biblioteca Lusitana, t. I, p. 91, com o título Vida dos Religiosos modernos que na Religião de Santo Agostinho florescerão em virtudes e vida religiosa?» Sebastião Toscano figura no elenco «Dos religiosos que servirão aos Reis». 
neo, amplamente corrobora: «No dejaré de hacer memoria del doctísimo y grande orador fray Sebastián Toscano, predicador (que hoy es) en Portugal, cuya elocuencia yo estimo en tanto que no sé si ninguno de nuestro tiempo le hace ventaja. Su loable conversación corresponde bien al herviente spíritu con que predica la palabra de Dios» (14).

Armando de Jesus Marques

(14) Gonçalo de Illescas, Historia Pontifical y Catholica, parte 1.a, Salamanca 1569 , f. 327. 


\begin{abstract}
O R A Ç Ã O
que fez o padre mestre frei Sebastião Toscano, em Santa Maria da Graça de Lisboa, a dezenove dias de Maio de MDLXVI, na trasladação dos ossos, da Índia a Portugal, do mui ilustre e mui excelente capitão e governador da Índia Afonso de Albuquerque
\end{abstract}

Com licença impressa Em a mui nobre e sempre leal cidade de Lisboa per Manuel João 
Píndaro, príncipe dos poetas líricos dos Gregos, havendo de contar e louvar as vitórias e grandezas de Hieron, rei da Sicília, não parece que teve conta com a invenção, gestos, pronunciação e outras partes do bom orador, mas somente com a graça, que tudo isto, e mais, dá no Céu e na terra, princípio de todo nosso merecimento e bem; como sem ela, cá em baixo entre os homens, nem lá em cima no Céu, nada se pode alcançar. Suas são do dito poeta estas palavras, nas quais, o que digo, diz:

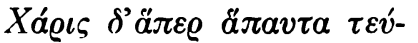

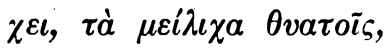

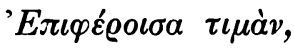

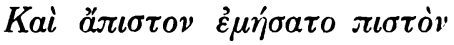

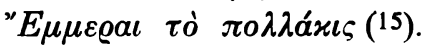

Pera eu contar as grandes vitórias do valeroso capitão e prudentíssimo governador da Índia Afonso de Albuquerque, não quero mais que a graça divina, e a vossa, dos que me ouvis. E por que tudo seja aceito a Deus, vamos seguros a buscar esta graça, e mais com tal aderência (16) como é a Rainha [fol. 2] do Céu, Maria, madre de graça. E por mais a obrigar, saudemo-la com o Anjo, dizendo: Ave, Maria, gratia plena! Ave!

O filho de Sirach, hebreu, por nome Jesu chamado, louvando os barões ilustres no seu livro Eclesiástico, nos amoesta, e persuade, louvar e celebrar o nome daqueles excelentes barões que, em forças de corpo e ânimo, antre os outros homens se mostraram, vivendo na terra como deuses (a que as gentes chamaram heroas), dizendo: Laudemus viros gloriosos et parentes nostros in generatione sua (17). "Louvemos - diz o Eclesiástico - os barões gloriosos e nossos maiores diante seus filhos e netos, e sua geração».

Averróis, comentador de Aristóteles, diz no livro de sua moral dou-

(15) A citação é tirada da $1 .^{\mathrm{a}}$ Ode Olímpica (Epodo IV), dedicada a Hierão I, rei de Siracusa, vencedor na corrida de cavalos (77.a Olimpíada, ano 472 a.C.).

(16) "Aderença (ou aderência), - segundo os filólogos seiscentistas, palavra primitivamente portuguesa - era o que hoje se chama empenhoca: o nepotismo c o favoritismo, a proteç̧ão, o valimento daqueles cujos partidários somos. Sem aderentes e parentes no paço, não se obtinha, segundo os Catões e Juvenais de então, emprego ou benesse algum; nem justiça ou promoção". Cf. CARolina Michaei is, Notas vicentinas, Lisboa 1949, p. 65, nota 120.

(17) Eccli. 44, 1. (A margem tem Ecli. 44). 
trina que o acatamento e reverência que fazemos aos homens em testimunho de sua virtude, se é secreto ou entre poucos, chama-se honra, e se, entre muitos, chama-se glória.

Assi que, diz o nosso Eclesiástico, que louvemos e honremos (18) [fol. 2v] nossos maiores com palavras, festas e alegrias, e com sinais de fora, que mostrem o que se deve aos barões ilustres e a nossos antepassados, por que os filhos e os netos, e todos seus descendentes, se esforcem com semelhantes spiritos, ou com maiores (se for possivel), imitá-los, assi os padres de nossa alma, que são nossos mestres e de quem algum ser spiritual recebemos, como os do corpo, que são os que este ser corporal, que de fora se vê, nos deram.

Muito desperta a virtude a memória dos barões ilustres, e mais se por algũa razão nos tocam. Porque, posto que a virtude e bondade nos obriguem a seu amor, o próprio bem de cada um move mais a seu possuidor. Amabile bonum, unicuique autem proprium, diz Aristóteles em sua moral doutrina $\left({ }^{19}\right)$. Quer dizer: "É muito pera amar o bem ou a bondade, mas cada um tem amor e afeição a suas cousas próprias».

Bom exemplo disto se vê naquele grande capitão Eneias (se o não fingiu o poeta Virgílio), quando, por cima das armas de que estava todo armado, abraçando a seu filho Ascânio, lhe disse que aprendesse dele a virtude e os verdadeiros trabalhos, e de outros a fortuna, encomendando-lhe muito que, logo que chegasse a tempo de poder vestir as armas, se alembrasse de seus avós, despertando-se com os bons exemplos de seu pai Eneias e de seu tio Heitor, como com sporas agudas. As palavras do poeta são estas: [fol. 3]

Disce, puer, virtutem ex me, verumque laborem, fortunam ex aliis. Nunc te mea dextera bello defensum dabit et magna inter praemia ducet. $\mathrm{Tu}$ facito, mox cum matura adoleverit aetas, sis memor et te animo repetentem exempla tuorum et pater Aeneas et avunculus excitet Hector (20).

(18) A margem tem: Honra. Gloria.

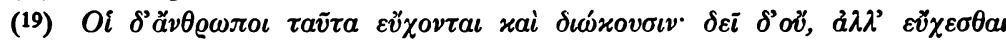

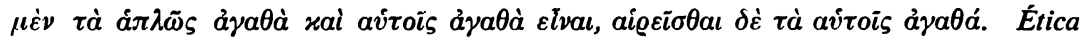
a Nicómaco, V, 1, 9 (Texto, tradução, prefácio e notas de Jean Voilquin, Paris 1950, p. 196).

(20) Eneida, XII, 435-440 (Trad. de André Bellesort, in ed. «Les Belles Lettres», t. II, Paris 1967, p. 211). A margem tem: Eneid. 12. 
Que não causou o nome de Vitorino, grande reitórico gentio, nos corações dos que o ouviram confessar a nossa santa fé católica, de um lugar alto, em público, quando a ela se converteu(21)? Que fez o grande africano Agostinho, quando Ponticiano lhe contou a santidade de António, monge de Egito (22)? Logo, com muita razão diz o Eclesiástico que louvemos os barões gloriosos, que souberam conquistar o Céu e tomá-lo por força (23).

(21) «Denique ut ventum est ad horam profitendae fidei, quae verbis certis conceptis retentisque memoriter de loco eminentiore in conspectu populi fidelis Romae reddi solet ab eis, qui accessuri sunt ad gratiam tuam, oblatum esse dicebat Victorino a presbyteris, ut secretius redderet, sicut nonnullis, qui verecundia trepidaturi videbantur, offerri mos erat; illum autem maluisse salutem suam in conspectu sanctae multitudinis profiteri. Non enim erat salus, quam docebat, in rhetorica, et tamen eam publice professus erat; quanto minus ergo vereri debuit mansuetum gregem tuum pronuntians verbum tuum, qui non verebatur in verbis suis turbas insanorum? Itaque ubi ascendit, ut redderet, omnes sibimet invicem, quisque ut eum noverat, instrepuerunt nomen eius strepitu gratulationis. Quis autem ibi non eum noverat? Et sonuit presso sonitu per ora cunctorum collaetantium: 'Victorinus, Victorinus'. Cito sonuerunt exsultatione, quia videbant eum et cito siluerunt intentione, ut audirent eum. Pronuntiavit ille fidem veracem praeclara fiducia, et volebant omnes rapere intro in cor suum. Et rapiebant amando et gaudendo: hae rapientium manus erant». S. August., Confessiones, VIII, 2, 5 (Texto bilingue, prefácio e notas de Ángel Custodio Vega, O.S.A., in ed. B.A.C., t. XI, Madrid 1963, pp. 304-305).

(22) A conversa de Ponticiano acerca de Santo Antão vem igualmente narrada nas Confissões de Santo Agostinho: «Quodam igitur die - non recolo causam, qua erat absens Nebridius - cum ecce ad nos domum venit ad me et Alypium Ponticianus quidam, civis noster, in quantum afer, praeclare in palatio militans: nescio quid a nobis volebat. Et consedimus, ut colloqueremur. (...) Cui ego cum indicassem illis me scripturis curam maximam impendere, ortus est sermo, ipso narrante de Antonio Aegyptio monacho, cuius nomen excellenter clarebat apud servos tuos, nos autem usque in illam horam latebat». VIII, 6, 14 (ed. cit., pp. 312-313).

Mas a famosa reacção de Santo Agostinho, a que talvez queira referir-se Sebastião Toscano, é a que se lê mais adiante: "Tunc in illa grandi rixa interioris domus meae, quam fortiter excitaveram cum anima mea in cubiculo nostro, corde meo, tam vultu quam mente turbatus invado Alypium, exclamo: 'Quid patimur? Quid est hoc, quod audisti? Surgunt indocti et caelum rapiunt, et nos cum doctrinis nostris sine corde ecce ubi volutamur in carne et sanguine! An quia praecesserunt, pudet sequi et non pudet nec saltem sequi...». VIII, 8, 19 (ed. cit., pp. 318).

Estes dois textos, e o da nota anterior, têm à margem: Aug., liv. 8 Conf., cap. 2 e 6.

(23) Faz referência ao vers. 3 do cap. 44: «Dominantes in potestatibus suis...». Mas tem presentes as frases de Jesus: «A diebus Ioannis Baptistae usque nunc, 
Diz mais: que se ajunte a Igreja pera celebrar seus louvores, como de homens que se não acabaram, mas melhoraram seu ser, pois seus corpos repousam em paz sperando o dia de Juizo, no qual se tornarão a unir e ajuntar com suas almas, pera nunca mais morrer, mas viver pera sempre com Deus. E seu nome não se acabará (24). Porque memória dos justos, como diz o real profeta David, será perpétua: In memoria aeterna erit, inquit, iustus (25).

Polo contrairo, a gente de que não temos conhecimento (nem há pera quê) foram uns homens que assi naceram como se nun-[fol. 3v]ca foram nacidos, acabaram como se nunca começaram, pereceram como se nunca tiveram ser, de cujo nome roga o profeta a Deus que não haja memória, nem crónica que deles fale, dizendo: Deleantur de libro viventium, et cum iustis non scribantur (26). Quer dizer: "Riscados e apagados sejam do Livro da Vida, e não se trate deles nas crónicas dos justos».

Aqueles dos quais se há-de falar e fazer memória são os que o nosso omnipotente Rei e Senhor nesta sua casa da Igreja sinalou, fazendo-os grandes ornamentos dela, servindo-se da música dos hinos e arpa de David (27), com que cantou o grande nome de Deus, e do sacerdócio

regnum caelorum vim patitur, et violenti rapiunt illud» (Mt. 11, 12); "Lex et prophetae usque ad Ioannem: ex eo regnum Dei evangelizatur, et omnis in illud vim facit» (Lc. 16, 16).

(24) Eccli. 44, 15: «Sapientiam ipsorum narrent populi, et laudem eorum nuntiet ecclesia». - 1 Cor. 15, 42-50: «Sic et in ressurrectione mortuorum. Seminatur in ignobilitate, surget in gloria: seminatur in infirmitate, surget in virtute...». - Rom. 6, 8-10: "Si autem mortui sumus cum Christo, credimus quia simul etiam vivemus cum Christo: scientes quod Christus resurgens ex mortuis iam non moritur mors illi ultra non dominabitur». - Eccli. 44, 14: "Corpora ipsorum in pace sepulta sunt, et nomen eorum vivit in generationem et generationem».

(25) Ps. 111, 7. (A margem tem: Ps. 111).

(26) Eccli. 44, 9: «Perierunt quasi qui non fuerint, et nati sunt quasi non nati». - Ps. 68, 29: «Deleantur de libro viventium, et cum iustis non scribantur». (A margem tem: Ps. 68).

(27) 2 Cor. 1, 21: «Qui autem confirmat nos vobiscum in Christo, et qui unxit nos Deus: qui et signavit nos, et dedit pignus Spiritus in cordibus nostris». Eph. 1, 13: «In quo et vos, cum audissetis verbum veritatis (Evangelium salutis vestrae), in quo et credentes signati estis Spiritu promissionis sancto»; 4, 30: «Et nolite contristare Spiritum sanctum Dei: in quo signati estis in diem redemptionis». Apoc. 7, 2-3: «Et vidi alterum angelum ... et clamavit ... dicens: Nolite nocere terrae, et mari, neque arboribus, quoadusque signemus servos Dei nostri in frontibus eorum»: 14, 1-2: «Et vidi: et ecce Agnus stabat supra montem Sion, et cum eo centum quadraginta quatuor millia, habentes nomen eius et nomen Patris eius scriptum in frontibus suis. Et audivi vocem de caelo, tanquam vocem aquarum multarum, et tanquam 
de Aarão, e da embaixada de seu irmão Mousés, na paz de uns e na guerra de outros. De alguns destes ilustres barões faz no dito lugar menção. O primeiro de que fala é Henoch, filho de Jared, do qual diz Mousés no livro da criação do mundo, que se chama Génesis, que andava com Deus e desapareceu, porque o levou Deus. Henoch, inquit, ambulavit cum Deo, et non apparuit, quia tulit illum Deus (28). Parece-vos que é pera louvar e honrar um homem que conversava com Deus? Certo, tal homem é muito pera louvar e, ainda, pera seguir; como é pera fugir de homens que andam com o demónio por caminhos dificultosos.

O lugar pera onde os santos dizem que Deus levou a Henoch [fol. 4] é o paraiso terreal, onde Deus por seus bons serviços o aposentou, dando-lhe ali vida descansada. E no tempo do Anticristo se tornará a servir dele. $E$ então, na fim do mundo, o acabará de apousentar no paraíso celestial da glória (29).

vocem tonitrui magni: et vocem, quam audivi, sicut citharoedorum citharizantium in citharis suis".

(28) Gen. 5, 23-24: «Et facti sunt omnes dies Henoch trecenti sexaginta quinque anni. Ambulavitque cum Deo, et non apparuit: quia tulit eum Deus». Eccli. 44, 16: "Henoch placuit Deo, et translatus est in paradisum, ut det gentibus poenitentiam»; 49, 16: «Nemo natus est in terra qualis Henoch, nam et ipse receptus est a terra». Hebr. 11, 5: «Fide Henoch translatus est ne videret mortem, et non inveniebatur: quia transtulit illum Deus: ante translationem enim testimonium habuit placuisse Deo». (Å margem tem: Enoch. Gen. 5).

(29) A notícia do Génesis relativa a Henoch constitui uma excepção se a compararmos com as dos outros patriarcas ante-diluvianos. Por um lado, encontramos a fórmula (duas vezes repetida): «andou com Deus». Por outro lado, em vez da indicação costumada - «e morreu», lemos de modo diferente - «e desapareceu, porque Deus o levou's.

A expressão "andar com Deus» denota uma santidade excepcional, muito diferente da que designam ordinariamente as fórmulas «andar diante de Deus» ou «perto de Deus». Daí, que a tradição judaica e cristã o tenha celebrado como modelo de todas as virtudes.

E que dizer do desaparecimento que parece substituir, nele, a morte natural? De acordo com muitos comentadores modernos, o facto de que Henoch «não viu a morte» (assim se exprime a Epístola aos Hebreus) significa muito simplesmente que Deus lhe concedeu um falecimento prematuro e suave, a fim de o preservar da morte punitiva do dilúvio.

Reportemo-nos, porém, à época em que Sebastião Toscano pronunciou a oração fúnebre de Afonso de Albuquerque e vejamos em que fontes se terá inspirado para falar de Henoch nos termos em que o faz.

Já a legenda judaica admitira que Henoch foi preservado da morte e transferido para o paraíso terreal (Livro dos Jubileus, 4, 23). O mesmo afirmou a tradição 
Do segundo, que é Lamech, filho de Noé, diz que foi barão santo $e$ justo, que, no tempo do geral dilúvio, reconciliou os homens com Deus, ofrecendo-lhe incenso agradável, com o qual assi aplacou a Deus, que lhe prometeu de se não indinar mais contra os homens com semelhante castigo de água (30).

$O$ patriarca Abraão naquela ordem é terceiro, ao qual, em seu tempo, não se achou igual em gloria, que assi conservasse a lei do Altissimo (31). Polo que seus descendentes - Isaac, Jacob e José - no mundo tem nome

cristã: tal como Elias, teria sido arrebatado vivo deste mundo e colocados ambos no Éden, donde viriam para exterminar o Anticristo com o preço do seu próprio sangue, constituindo as duas testemunhas de Cristo referidas no Apocalipse.

Assim o afirmam, por exemplo, S. Jerónimo e Tertuliano: «Henoch translatus est in carne (Gen. 5, 24). Elias carneus raptus est in caelum (IV Reg. 2, 11). Necdum mortui, et paradisi iam coloni...» (S. Hieron., Contra Ioannem Hierosolym., num. 29; ML 23, 398 B); «Translatus est Henoch et Elias, nec mors eorum reperta est, dilata scilicet. Caeterum morituri (Apoc. 11, 3-12) reservantur, ut Antichristum sanguine suo extinguant» (TeRT., Liber de anima, cap. L; ML 2, 735 A).

Cf.: Cón. José Falcão, $O$ Novo Testamento (trad. do texto grego, introduções e notas pelo ...), II - 2. ${ }^{\text {a }}$ P. ${ }^{\text {te }}$, Lisboa 1965, pp. 160 e 419; L. Pirot - A. Clamer, La Sainte Bible, I, 1. ${ }^{\text {a }}$ P.tc Paris 1953, p. 168; P. E. TeSTA, Genesi (Introduzione - Storia primitiva a cura di ...) in «La Sacra Bibbia», Torino-Roma (Marietti) 1969, p. 358; Enciclopedia de la Biblia, III, Barcelona [1963], cols. 34-37.

(30) Lamech foi pai, não filho, de Noé: «Vixit autem Lamech centum octoginta annis, et genuit filium: vocavitque nomen eius Noe...» (Gen. 5, 28-29). Do mesmo modo, foi Noé, não Lamech, o varão santo e justo que aplacou a Deus, alcançando dele que não punisse a humanidade com novo dilúvio: «Noe vero invenit gratiam coram Domino. Hae sunt generationes Noe: Noe vir iustus atque perfectus fuit in generationibus suis, cum Deo ambulavit» (Gen. 6, 8-9); "Aedificavit autem Noe altare Domino: et tollens de cunctis pecoribus et volucribus mundis, obtulit holocausta super altare. Odoratusque est Dominus odorem suavitatis, et ait: Nequaquam ultra maledicam terrae propter homines: sensus enim et cogitatio humani cordis in malum prona sunt ab adolescentia sua: non igitur ultra percutiam omnem animam viventem sicut feci» $(8,20-21)$; «Statuam pactum meum vobiscum, et nequaquam ultra interficietur omnis caro aquis diluvii, neque erit deinceps diluvium dissipans terram» $(9,11)$.

Lugar paralelo do Eclesiástico, que é o que Toscano no texto segue mais de perto: «Noe inventus est perfectus, iustus, et in tempore iracundiae factus est reconciliatio. Ideo dimissum est reliquum terrae, cum factum est diluvium. Testamenta saeculi posita sunt apud illum, ne deleri possit diluvio omnis caro» (44, 17-19).

A margem tem: Noe. Gen. 5. Gen. 6 e 8 e 9.

(31) Eccli. 44, 20: "Abraham magnus pater multitudinis gentium, et non est inventus similis illi in gloria; qui conservavit legem Excelsi, et fuit in testamento cum illo». 
imortal. Diga Chodola, o mor rei dos Elamitas, e Amrafel, rei de Senaar, e Arioch, rei de Ponto, e Tadal, rei dos gentios, a força de sua spada, quando, com a vitória tornando a sua terra, lhe ofreceu sacrifício Melquisedech, sacerdote do Altissimo e rei de Salém (32).

Mas, deixadas as grandezas e vitórias dos barões gloriosos dos tempos passados (porque imos muito depressa), visto que eles merecem honra e gloria por sua bondade, vejamos que género de bens é este que faz os homens gloriosos, por que o possamos adquirir e, com ele, alcancar honra [fol. 4v] e glória.

O Mestre das Sentenças diz que hai três géneros de bens: uns grandes, e outros pequenos, e outros meãos. Os bens grandes são as virtudes; os pequenos são os bens do corpo; os meãos são as potências da alma - memória, entendimento e vontade, com o livre alvidrio do homem (33).

Dos primeiros bens, que são virtudes, não podemos mal usar. Mas dos segundos bens que são os do corpo, e dos terceiros, que são as potências da alma, destes podemos usar mal e bem.

Os bens meãos não nos podem fazer por si gloriosos porque aquilo que temos por natureza, como diz Aristóteles, não nos pode dar honra,

(32) Gen. 14, 1-24: "Factum est autem in illo tempore, ut Amraphel rex Sennaar, et Arioch rex Ponti, et Chodorlahomor rex Elamitarum, et Thadal rex gentium inirent bellum contra...». ( $\AA$ margem tem: Gen. 14).

(33) «Si vero quaeritur quomodo ipsa gratia praeveniens mereatur augeri et perfici, cum nullum meritum sit absque libero arbitrio: et quid sit ipsa gratia, an virtus, an non; et si virtus, an actus vel non: ut hoc aperte insinuari valeat, praemittendum est tria esse genera bonorum. Alia namque sunt magna, alia minima, alia media, ut Augustinus ait in primo Retract.. Virtutes, inquit, quibus recte vivitur, magna bona sunt. Species autem quorumlibet corporum sine quibus recte vivi potest, minima bona sunt. Potentiae vero animi, sine quibus recte vivi non potest, media bona sunt. Item, lib. 2 de lib. Arbit., c. 19, in tomo 1: Virtutibus nemo male utitur. Caeteris autem bonis, id est, mediis et minimis, non solum bene, sed etiam male quisque uti potest; et ideo virtute nemo male utitur, quia opus virtutis est bonus usus istorum quibus etiam non bene uti possumus. Nemo autem bene utendo, male utitur; non solum autem magna, sed etiam media, et minima bona esse praestitit bonitas Dei. Ecce habes tria genera bonorum distincta. Petrus LOMBARdus, Sententiarum libri quatuor, lib. II, dist. XXVI, 10 (ML 192, 713). A margem tem: Magister 2 Sent. d. 27. Três maneiras de bens.

Textos de Santo Agostinho que Pedro Lombardo cita e praticamente reproduz: Retractationes, lib. I, cap. IX, 4 (ML 32, 597); De libero arbitrio, lib. II, cap. XIX, 50 (ML 32, 1267-1268). 
nem menos vitupério (34). Quem se pode com razão gloriar de ter bom entendimento, pois que o tal the pode ser ocasião de se perder, usando dele mal? $O$ que digo do entendimento, digo da memória, vontade $e$ livre alvidrio, das quais cousas posso bem e mal usar.

Pois do outro género de bens, que são riquezas e contentamentos corporais, menos podemos gloriar-nos, porque os uns nos pode tirar um ponto da carta maligna do jogo ou do venturoso dado, e o cavalo, dama ou rei de pau, que não tem valia senão no tabuleiro ou enxadrez. Como nos podem fazer gloriosos e ilustres aqueles bens, dos quais os uns nos leva o vento, os outros o jogo, e, fi-[fol. 5]nalmente, a todos eles acaba o tempo? E por que acabe com ũa palavra, digo que, sendo o homem criado de Deus pera cousas grandes, não se deve gloriar, nem cuidar que é grande por ter cousas que ainda os bárbaros, gentios e homens pequenos não ousam chamar cousas grandes, nem ainda lhe chamam bens, mas bens aparentes $e$ pequenos.

Fica o terceiro género de bens grandes, que são as virtudes, como joias de Deus, com que Ele afermosenta as almas, lançando-as do Céu, como gotas de orvalho nas conchas, de que se geram as perlas. São estes bens chamados virtudes, que quer dizer forças, ou poderes, porque são as virtudes poderosas, porque podem fazer (e de feito fazem), aos que as posseem, grandes e poderosos. A estes bens se deve a honra $e$ glória, como sua verdadeira paga.

Destas virtudes, a fé é a primeira, como fundamento de nosso spiritual edifício. Esta, como diz o sumo pontifice São Pedro, purifica os corações (35), e se os homens são limpos, eles são ilustres. A glória, triunfos e vitórias desta virtude teológica screve seu fiel cronista São Paulo na carta que screveu aos Judeus. Se quereis ver as forças dessa virtude, lede as crónicas dos excelentíssimos e vitoriosos capitães Abraão, Gedeão,

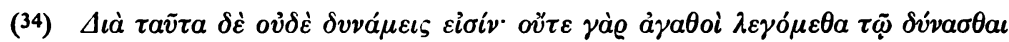

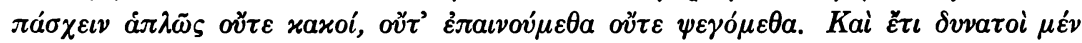

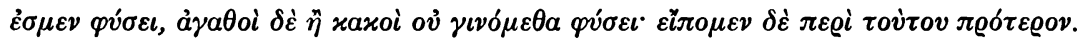
Ét. Nicóm., II, 5, 5 (ed. cit., p. 66).

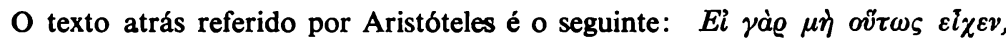

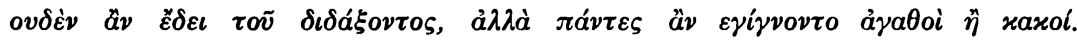
II, 1,7 (p. 54).

(35) «Et qui novit corda Deus, testimonium perhibuit, dans illis Spiritum sanctum, sicut et nobis, et nihil discrevit inter nos et illos, fide purificans corda eorum» (Act. 15, 8-9). A margem tem: Virtudes. Fé. Act. 15. 
Barach, Sansão, David, Jefté, e do grande Judas Macabeu, e Josué - os quais, pola fé, [fol. 5v] venceram os reinos e, à força de braços, desqueixaram os ussos $e$ os leões, e amansaram a fúria daquele poderoso elemento do fogo. Foram nas batalhas mui fortes, desbarataram os reais de seus imigos (36).

Quem dirá os poderes da segunda virtude da sperança, singular dom (como diz o bom rei e profeta David) dos homens (37)? Esta é a segura âncora da nossa alma, que nos fez firmes nas crecidas e levantadas ondas que subem ao céu, no cabo de nossas boas speranças, aferrando com $\tilde{u} a$ de suas orelhas na firme pedra nossa, Cristo, tendo outra na terra, de que foi formada nossa natureza (38). Lede as crónicas dos patriarcas e profetas, que nada quiseram na terra, fogo, nem logo (como desterrados), nem casas de paus, pedras, lodo e palhas, porque speravam de se apou-

(36) Citação quase literal de Hebr. 11, 32-34: «Et quid adhuc dicam? Deficiet enim tempus enarrantem de Gedeon, Barac, Samson, Iephte, David, Samuel, et prophetis: qui per fidem vicerunt regna, operati sunt iustitiam, adepti sunt repromissiones, obturaverunt ora leonum, extinxerunt impetum ignis, effugerunt aciem gladii, convaluerunt de infirmitate, fortes facti sunt in bello, castra verterunt exterorum».

(37) Toscano não se refere aqui a nenhum lugar dos Salmos em particular. Tendo sido, como foram, as orações do Antigo Testamento em que o próprio Deus inspirou aos seus filhos os sentimentos que deviam ter a seu respeito, os Salmos são gritos de louvor, de súplica, de acção de graças em que a virtude da esperança se encontra disseminada por toda a parte. ( $\AA$ margem tem: Sperança).

(38) ... que nos fez firmes nas crecidas e levantadas ondas que subem ao céu .... «Dixit, et stetit spiritus procellae, et exaltati sunt fluctus eius. Ascendunt usque ad caelos, et descendunt usque ad abyssos; anima eorum in malis tabescebat. Turbati sunt et moti sunt sicut ebrius; et omnis sapientia eorum devorata est. Et clamaverunt ad Dominum cum tribularentur; et de necessitatibus eorum eduxit eos. Et statuit procellam eius in auram et siluerunt fluctus eius» (Ps. 106, 25-30).

... aferrando com ũa de suas orelhas na firme pedra nossa, Cristo...: «superaedificati super fundamentum apostolorum, et prophetarum, ipso summo angulari lapide Christo Iesu» (Eph. 2, 20); «Fundamentum enim aliud nemo potest ponere praeter id quod positum est, quod est Christus Iesus» (1 Cor. 3, 11); «Ad quem accedentes lapidem vivum, ab hominibus quidem reprobatum, a Deo autem electum, et honorificatum: et ipsi tanquam lapides vivi superaedificamini, domus spiritualis, sacerdotium sanctum, offerre spirituales hostias, acceptabiles Deo per Iesum Christum. Propter quod continet Scriptura: ecce pono in Sion lapidem summum angularem, electum, pretiosum: et qui crediderit in eum, non confundetur. Vobis igitur honor credentibus: non credentibus autem lapis, quem reprobaverunt aedificantes, hic factus est in caput anguli: et lapis offensionis, et petra scandali, his qui offendunt verbo, nec credunt in quo et positi sunt» (1 Petr. 2, 4-8). 
sentar em ũa casa feita da mão de Deus (39). Esta virtude os fez gloriosos vencedores, como diz o real profeta David: In te speraverunt patres nostri; speraverunt et liberasti eos (40). «Venceram, Senhor, nossos padres porque em ti se confiaram, e puseram na bondade tua suas esperanças». Um glorioso barão destes dezia, quando alçava os olhos ao céu e via sua fermosura: Videbo coelos tuos, opera digitorum tuorum; lunam et stellas, quae tu fundasti (41). Spero, Senhor - dizia Davidque hei-de ver, e saber, que obra é essa tão rica que lá tens [fol. 6] em cima, nesses céus, sol, lua e strelas, obra prima de teus dedos. Disto serão os maus privados, que não pisarão com seus pés, nem tocarão com suas mãos as strelas, nem saberão que cousa é esta que cá vemos de fora nesta abóbada do céu, porque vivos descenderão aos infernos, como a gente revoltosa e murmuradora, de Coré, Datan e Abiron (42), sem nunca subir ao Céu, nem ver sua glória.

A terceira virtude teológica, que chamam caridade, também faz os homens ilustres e gloriosos. Se um homem por ser privado de um rei é ilustre e grande, que será aquele no qual Deus pôs seu coração e passeia por sua alma (43), como um príncipe per sua varanda? Estes amigos de Deus são os que verdadeiramente são honrados, ilustres e gloriosos, como o diz o profeta David: Nimis honorati sunt amici tui Deus; nimis confortatus est principatus eorum (44). - $\delta$ Deus, diz David, como são honrados os vossos amigos! Seu stado e principado é mui seguro, que ninguém lho poderá tirar, como aos reis da terra, que hoje tem grande ser e amenhã são nada, nem há deles memória.

Valha-me Deus, onde nos leva a virtude. Não menos, que ao Céu. Ora, como não chamaremos gloriosos aos barões virtuosos?

(39) Hebr. 11, 8-10: «Fide qui vocatur Abraham oboedivit in locum exire, quem accepturus erat in haereditatem: et exiit, nesciens quo iret. Fide demoratus est in terra repromissionis, tanquam in aliena, in casulis habitando cum Isaac et Iacob cohaeredibus repromissionis eiusdem. Expectabat enim fundamenta habentem civitatem: cuius artifex et conditor Deus». (A margem tem: Heb. 11).

(40) Ps. 21, 5. (À margem tem: Ps. 21).

(41) Ps. 8, 4. (Å margem tem, erradamente: Ps. 9).

(42) Num. 16, 31-33: "Confestim igitur ut cessavit loqui, dirupta est terra sub pedibus eorum: et aperiens os suum, devoravit illos cum tabernaculis suis et universa substantia eorum, descenderuntque vivi in infernum operti humo, et perierunt de medio multitudinis». (À margem tem: Num. 16).

(43) Lev. 26, 12: «Ambulabo inter vos, et ero Deus vester, vosque eritis populus meus». (A margem tem: Caridade. Lev. 26).

(44) Ps. 138, 17. (A margem tem: Ps. 138). 
Posto que estas três virtudes teológicas de que acima temos falado (que são fé, sperança e caridade) são as que [fol. 6v] principalmente dão ao homem honra e glória, nem por isso se devem defraudar as virtudes morais de sua glória e valia, porque nem as teológicas podem estar sem as morais (scilicet, temperança, prudência, fortaleza e justiça), nem estas sem a caridade, que é a alma de todas as virtudes, podem ser perfeitas; mas de todas se faz ũa rica cadeia, mais preciosa que do ouro obrizo que a terra Evilath cria, rematada com toda a pedraria que no Oriente e Ocidente achar se pode (45).

Estes são os barões honrados, ilustres e gloriosos, os quais a tal cadeia de virtudes afermosenta; e aquele terá mais glória, que maior parte tever dela.

Pois sabemos donde nace a gloria e honra, cuja é, e a quem se deve dar, louvemos - como diz o filho de Sirach - os barões gloriosos, que são os virtuosos: Laudemus viros gloriosos et parentes nostros in generatione sua.

Mas a quem louvaremos primeiro? Porque, destes homens, cria muitos a nossa terra de Portugal no Ocidente e a do Oriente, como quem bem o sabe, que assi o confessa:

Quem virum, aut divum, resonare quem vis,

Inclitum heroum, mihi dic precor te,

Pectinis gratis modulis eburni

Calliopea? (46)

(45) Gen. 2, 10-12: «Et fluvius egrediebatur de loco voluptatis ad irrigandum paradisum, qui inde dividitur in quatuor capita. Nomen uni Phison: ipse est qui circuit omnem terram Hevilath, ubi nascitur aurum: et aurum terrae illius optimum est: ibi invenitur bdellium, et lapis onychinus». Iob, 28, 15: «Non dabitur aurum obrizum pro ea, nec appendetur argentum in commutatione eius». Dan. 10, 5: «Et levavi oculos meos, et vidi: et ecce vir unus vestitus lineis, et renes eius accincti auro obrizo".

(46) Trata-se de uma imitação de Horácio, em versos sáficos. O lugar é o seguinte:

$$
\begin{aligned}
& \text { Quem virum aut heroa lyra vel acri } \\
& \text { Tibia sumes celebrare, Clio? } \\
& \text { Quem Deum? cuius recinet jocosa } \\
& \text { Nomen imago, }
\end{aligned}
$$

Ode XII (liber I), 1-4.

A imitação será da autoria de Frei Sebastião Toscano? A dúvida nasce do que ele próprio afirma: "como quem bem o sabe, que assi o confessa: ...». De 
[fol. 7] Deixados os outros pera seus tempos, agora louvaremos o nosso virtuoso, mui ilustre capitão e excelente governador da Índia Afonso de Albuquerque (47), grande honra e gloria da terra nossa por virtude, esforço e sangue real; barão glorioso, temor, espanto das nações bárbaras, dos mouros e gentios de Oriente; e, aos seus ocidentais, companheiro benigno e suave. Luz e sol ardentíssimo, lá, na manhã onde nace; fresca e temperada nuve, cá, onde esta tarde anoitece, e repousa debaixo desse rico pano de ouro, que aí vedes.

Ai jaz, não corpo morto, mas ũa como rica bainha da segura e talhante spada de sua alma, vivo spírito na glória, que, no dia do final juízo, virá a esta casa de Santa Maria da Graça, onde invistirá e encherá outra vez a sua bainha, na ressurreição de toda carne (48) (que ele, com viva fé, aqui spera).

Quando a voz mui soante da trombeta do Arcanjo (49), chamados os mortos a dar conta de sua vida, a dará ele (na carne em que verá o seu Senhor) (50) mui certa e mui inteira. As forças de sua spada, a prudência no governo e tratar as cousas da guerra, seus bem afortunados acometimentos, seus bravos assaltos contra os inmigos, seus prósperos sucessos,

qualquer modo, notemos a feliz substituição de Clio, musa da história, por Caliopeia, deusa da eloquência.

(47) A margem tem: Afonso de Albuquerque.

(48) Ideia tipicamente paulina da ressurreição, embora com uma certa formulação platónica. Quanto a S. Paulo, ver, por exemplo, 1 Cor. 15, 53-54: «Oportet enim corruptibile hoc induere incorruptionem: et mortale hoc induere immortalitatem. Cum autem mortale hoc induerit immortalitatem, tunc fiet sermo, qui scriptus est: Absorpta est mors in victoria». Relativamente à coloração platónica da frase, cf. nota 102.

Dada a filiação augustiniana de Toscano, não parece fora de propósito referir igualmente o seguinte texto de Santo Agostinho: «Nec ideo tamen contemnenda et abjicienda sunt corpora defunctorum, maximeque iustorum ac fidelium, quibus tanquam organis et vasis ad omnia bona opera sancte usus est spiritus». De cura pro mortis gerenda, III, 5 (ML 40, 595). Cf. também De civitate Dei, I, 13 (ML 41, 27).

(49) Mt. 24, 31: «Et mittet angelos suos cum tuba, et voce magna: et congregabunt electos eius a quatuor ventis, a summis caelorum usque ad terminos eorum». l Cor. 15, 52: "In momento, in ictu oculi, in novissima tuba: canet enim tuba, et inortui resurgent incorrupti: et nos immutabimur». 1 Thess. 4, 15: "Quoniam ipse Dominus in iussu, et in voce archangeli, et in tuba Dei descendet de caelo: et mortui, qui in Christo sunt, resurgent primi».

(50) Iob 19, 25-26: "Scio enim quod Redemptor meus vivit, et in novissimo die de terra surrecturus sum; et rursum circumdabor pelle mea, et in carne mea videbo Deum meum». 
a fé e lealdade a seu rei, seus muitos e grandes serviços, os duros trabalhos da guerra, os pe-[fol. 7v]rigos do mar, os enfadamentos da terra, o sofrimento da gente desmandada, que, como tempestade e tormenta desfeita, às vezes se levanta, quando o furor lhe dá, e ministra novas, e não cuida das armas (51) - não direi.

Nem menos direi quão fácil era a todos, quão temido dos inmigos, dos amigos quão amado, quão vitorioso nas batalhas, sendo sempre vencedor, posto que muitas vezes ferido, por que fosse seu corpo um certo e fiel tombo dos padrões e scrituras de seus muitos e grandes merecimentos.

Tão pouco direi quão presto era no obrar, depois de maduro e vagaroso conselho (52); quão misericordioso com os pupilos e viúvas (53), e com todo género de míseros, sem faltar da justiça um ponto; quão largo nas mercês, que jamais lhe pediram cousa sua, que a negasse, como quem lera ao Santo Evangelho - Date a quantos te pedirem (54) (porque as mercês que os reis da Índia lhe faziam, sendo muitas, não as guardava pera si, mas logo polos seus as repartia); quão honesto em seu falar; quão cauto no jurar, que, quando lhe parecia que tinha necessidade de juramento, não punha a boca em Deus, mas somente dezia-Arrenego da vida, que vivo!, juramento mui semelhante aos dos santos Job e Jeremias (55).

(51) Este belo trecho faz lembrar pelo ritmo, e até pelas ideias, 2 Cor. 11, 26-28: «in itineribus saepe, periculis fluminum, periculis latronum, periculis ex genere, periculis ex gentibus, periculis in civitate, periculis in solitudine, periculis in mari, periculis in falsis fratribus: in labore et aerumna, in vigiliis multis, in fame et siti, in ieuniis multis, in frigore et nuditate, praeter illa quae extrinsecus sunt, instantia mea quotidiana, sollicitudo omnium Ecclesiarum».

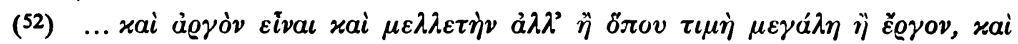

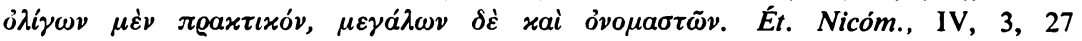
(ed. cit., p. 170).

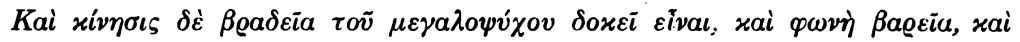

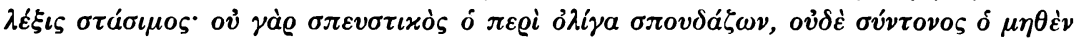

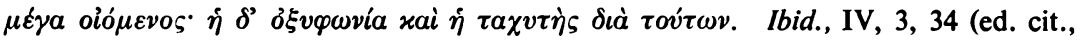
pp. 170-172).

(53) Iac. 1, 27: «Religio munda et immaculata apud Deum et Patrem, haec est: Visitare pupillos et viduas in tribulatione eorum, et immaculatum se custodire ab hoc saeculo".

(54) Lc. 6, 30: «Omni autem petenti te, tribue: et qui aufert quae tua sunt, ne repetas». ( $\AA$ margem tem: Luc. 6).

(55) O juramento normal no Antigo Testamento, e também em Job e Jeremias, é: "Vive Deus que...». Assim, Iob 27, 1-4: "Vivit Deus (...) non loquentur labia mea iniquitatem, nec lingua mea meditabitur mendacium». Ier. 4, 2: «Et iurabis: Vivit 
Nada destas particularidades direi, porque o tempo é breve e porque disto dizem muito suas crónicas. E, sobretudo, porque nunca foi meu intento [fol. 8] trabalhar por louvar forças do corpo, nem cousa que se acaba, mas forças do ânimo e virtudes, com que se fazem maiores vitórias, e fazem aos homens gloriosos. E ainda disto direi mui pouco, porque esta é oração e não crónica.

Que direi? Donde começarei?, - que me chamam e acenam mil cousas: e cada ũa dela diz que dela o louve: e eu, vendo tantas, não posso pelo streito lugar satisfazer a só ũa...

Digamos, primeiro, do seu grande nome Albuquerque, que põe em cuidado minha alma e me roga que primeiro o louve (56).

Outro nome, que o de Mecenas, é o nosso Albuquerque:

Albuquerque, atavis edite regibus,

$O$ et praesidium et dulce decus meum!

Sunt quos curriculo pulverem Olympicum

Collegisse iuvat, metaque fervidis

Evitata rotis, palmaque nobilis

Terrarum dominos evehit ad deos.

..

Si me oratoribus tuis inseris

Sublimi feriam sidera vertice (57).

Dominus! In veritate, et in iudicio, et in iustitia; et benedicent eum gentes, ipsumque laudabunt». Decerto, há outras expressões mais próximas da do texto (cf., v.g., Iob 3, 3 e Ier. 20, 14), mas não são fórmulas de juramento.

(56) À margem tem: Do nome Albuquerque.

(57) Nesta passagem da oração fúnebre, Sebastião Toscano volta a evocar Horácio. O lugar em que se estriba é o seguinte:

1 Maecenas, atavis edite regibus, $O$ et praesidium et dulce decus meum!

Sunt quos curriculo pulverem olympicum

Collegisse iuvat; metaque fervidis

Evitata rotis, palmaque nobilis

Terrarum dominos evehit ad deos.

...

35 Quod si me lyricis vatibus inseres,

Sublimi feriam sidera vertice.

Ode I (liber I), 1-6; 35-36.

Como se vê, o orador fez apenas duas substituições: a de «Maecenas» por «Alboquerque» no v. 1; e a de «Quod si me lyricis vatibus inseres» por «Si me ora- 
Melhor lhe convém ao nosso Mecenas Afonso de Albuquerque estes versos, que ao de Horácio: porque outros reis, outros principes, outros capitães, outros ilustres cavaleiros e senhores são estes; e outros aqueles, outros os Mecenates. Como agora vereis polo fundador deste nome Albuquerque.

[fol. 8v] O primeiro fundador da vila de Albuquerque foi $D$. Afonso Teles de Meneses, o Velho, que casou com Dona Tereja, filha de D. Sancho, rei de Portugal, primeiro deste nome (58).

Ao tempo que naquela sua terra se fundava a fortaleza, estava no sitio dela um carvalho branco, do qual foi posto à vila este nome Albuquerque, vocábulo latino que quer dizer na nossa lingua portuguesa carvalho branco, como pronóstico e preságio, ou bon agouro, do felice sucesso que havia de ter esta casa, significado pola brancura e fortaleza daquele santo castelo de Sião (59) da glória - como vemos, na Sagrada Scritura,

toribus tuis inseris» no v. 35. Mas a métrica da ode (cujo verso é um asclepiadeu menor ou coriambo, conforme a maneira de medir) não foi respeitada.

Para que o termo "Alboquerque» não viesse alterar a dita métrica, seria

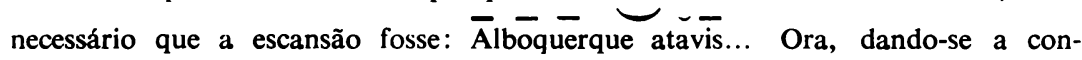
tracção das duas sílabas «que» e «a», a sílaba daí resultante será longa, a saber: Ālboquerque atavis... Parece-nos sobremaneira difícil justificar tal irregularidade.

Parece-nos mais difícil ainda, senão impossível, justificar o v. 35 . E isto não apenas pela dificuldade do termo «oratoribus», — onde, para ficar salvaguardada a métrica, a escansão deveria ser Sĩ me orātōriłbūs..., com um «to» breve (sendo que a sílaba «to» é de sua natureza larga...); mas porque, admitindo mesmo, por licença poética, a sílaba «to» como breve, falta um pé dáctilo depois de «oratoribus», pé que não pode ser suprido pela palavra «tuis».

Em resumo: apesar do que diz o mestre Horácio - Pictoribus atque poetis / quidlibet audendi semper fuit aequa potestas - (Arte Poética, 9-10), não nos atrevemos a ádmitir como poéticas as substituições de Frei Sebastião Toscano. Ao mudar as palavras de Horácio por outras, quer no v. 1, quer no 35, supomos que pretendeu apenas fazer substituições acomodatícias, sem atender à métrica. E isto sem grande desdouro para si.

(58) À margem tem: Fundação da casa Albuquerque.

(59) «Originariamente nombre de la fortaleza de los jebuseos sobre la colina oriental, entre el Tiropeón y el torrente Cedrón de la Jerusalén posterior». Cf. H. HaAg (e outros), Diccionario de la Biblia, Barcelona 1967, col. 1870.

«La literatura cristiana ve el cumplimiento de estas esperanzas del A. T. [de salvação, numa nova cidade, construída pelo Deus vivo, com grande magnificência] en la fundación del reino de Dios; por eso Pablo llama a la Iglesia de Cristo «la 
que os anjos se descrevem fortes e vestidos de roupas brancas, como lemos que apareceram na ressurreição e ascensão de Nosso Senhor Jesu Cristo com stolas brancas $\left({ }^{60}\right)$.

Nesta casa sucedeu o conde D. Afonso Teles de Meneses, seu bisneto, que casou em Castela com Dona Tereja, filha del rei D. Sancho, da qual houve ũa filha que se chamou, como a mãe, Dona Tereja. Esta filha casou com D. Afonso Sanches, filho del rei D. Dinis, o qual teve um filho que se chamou $D$. João Afonso de Albuquerque, primeiro deste nome. De maneira que o primeiro que fundou a vila de Albuquerque se chamou D. Afonso Teles de Meneses, o Velho; e o primeiro que se chamou [fol. 9] Albuquerque foi $D$. João Afonso de Albuquerque, neto del rei D. Dinis (61).

Destes Albuquerques descende o nosso capitão e governador Afonso de Albuquerque, de que falamos, filho de Gonçalo de Albuquerque, geração dos reis de Ocidente (de que dão testemunho suas armas, que tem as quinas reais) e senhor, pois os venceu, dos reis de Oriente.

Seja, pois, este o primeiro que dizemos de seus louvores, scilicet, descender de três reis, servir a três reis, e assemelhar-se a três famosissimos capitães, e fundar a três senhaladas fortalezas (62).

$O$ s três reis de que descende foram: el-rei $D$. Sancho, primeiro deste nome, e D. Dinis, reis de Portugal; e D. Sancho, rei de Castela.

Jerusalén de arriba» (Gal. 4, 26) y Heb. 12, 22 la denomina «monte Sión, ciudad del Dios vivo, Jerusalén celestial». Ap. 14, 1 llama al cielo monte Sión y Ap. 21, 9-27 ve en la Jerusalén celestial la imagen de la Iglesia de Dios en su triunfo glorioso". Ibid., col. 960 .

A brancura a que Sebastião Toscano alude no texto decerto que se refere a Apoc. 21, 11: «... habentem claritatem Dei: et lumen eius simile lapidi pretioso tanquam lapidi iaspidis, sicut crystallum».

Cf. ainda Lexicon Biblicum editore Martino Hagen, S. J., III, Paris 1911, cols. 1024-1025.

(60) Na Ressurreição: «Erat autem aspectus eius sicut fulgur: et vestimentum eius sicut nix» $(M t .28,3)$; «Et introeuntes in monumentum viderunt iuvenem sedentem in dextris, coopertum stola candida, et obstupuerunt» (Mc. 16, 5); «Et factum est, dum mente consternatae essent de isto, ecce duo viri steterunt secus illas in veste fulgenti» (Lc. 24, 4); «Et vidit duos angelos in albis, sedentes, unum ad caput, et unum ad pedes, ubi positum fuerat corpus Iesu» (Ioan. 20, 12).

$\mathrm{Na}$ Ascenção: «Cumque intuerentur in caelum euntem illum, ecce duo viri astiterunt iuxta illos in vestibus albis» (Act. 1, 10).

(61) A margem tem: Primeiro Albuquerque.

(62) A margem tem: Primeiro louvor de Afonso de Albuquerque. 
Os três reis a que serviu foram: $D$. Afonso quinto, e $D$. João, o segundo, cujo stribeiro-mor foi, e o invictíssimo rei D. Manuel, primeiro deste nome, o qual primeiro o mandou por capitão geral à Índia.

Os três reis que venceu foram o de Ormuz, e o de Malaca, e o de Goa, cujas três bandeiras, com suas divisas, ai vedes dependuradas nessa capela-mor, as quais venceu com essa, rota, que no meio dessa capela está, cheia de grandes vitórias, a qual lhe deu o mui poderoso rei D. Manuel, quando o mandou à Índia, a oito dias do mês de [fol. 9v] Abril, ano de mil e quinhentos e seis. E ele perdeu a vida (se ele pode morrer, ou perdê-la), mas não perdeu a bandeira. Porque, daquele dia que el-rei lha deu a sessenta anos, aos mesmos oito dias do dito mês de Abril, ano de mil e quinhentos e sessenta e seis, a tornou a trazer morto, quando da Índia neste porto de Lisboa entrou sua ossada.

$O$ leal, ó fiel, ó poderoso cavaleiro (não daqueles que os Gregos chamam ripsáspidas (63)), cujas vitórias e maravilhas, se começássemos a contar, a noite nos tiraria o dia!

Foi semelhante a três capitães dos maiores que no mundo houve, imitando a cada um deles na virtude em que foi mais assinado: ao grande Cipião Africano, na fortaleza; a Fábio Máximo, na prudência e magnanimidade; e na piedade a Eneias, do qual diz Virgílio - Insignem pietate virum (64). E de Fábio Máximo diz Énio, em seu louvor e glória: Unus

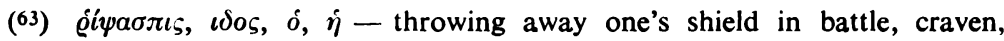
Ar. Nu. 353, Pax 1186, Pl. Lg. 944b. LidDEL and ScoTt, A Greek-English Lexicon,

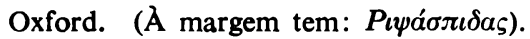

(64) Sebastião Toscano tomou de Virgílio as três comparações, embora só o afirme explicitamente da última. Eis os respectivos lugares:

Quis te, magne Cato, tacitum aut te, Cosse, relinquat?

Quis Gracchi genus aut geminos, duo fulmina belli,

Scipiadas cladem Libyae, paruoque potentem

Fabricium uel te sulco, Serrane, serentem?

Quo fessum rapitis, Fabii? tu Maximus ille es,

unus qui nobis cunctando restitues rem.

Eneida, VI, 841-846.

Musa, mihi causas memora, quo numine laeso

quidve dolens regina deum tot uoluere casus

insignem pietate uirum, tot adire labores

impulerit. Tantaene animis caelestibus irae?

Eneida, I, 8-11.

À margem tem: Cipião Africano. Fábio Máximo. Eneias. Eneida, 1.․ 
homo nobis cunctando restituit rem. Non ponebat enim rumores ante salutem (65), como o refere o heróico poeta Virgílio no sexto da Eneida. $E ́$ próprio dos príncipes e grandes capitães ser magnânimos, e não solicitos curiosamente de cada cousa, mas daquelas que convém a seu stado. Por muitas há-de passar, muitas há-de dissimular, muitas há-de sofrer, e não se há-de ha-[fol. 10]ver por achado em todas (66).

Aristóteles, falando no quarto da Ética do barão magnânimo, diz que o tal há-de ser vagaroso (67). Quer dizer, que há-de refrear a cólera não se movendo de ligeiro, mas há-de consultar devagar, e o bem consultado obrá-lo logo.

(65) Também Énio se refere, na verdade, a Fabius Maximus Cunctator, num fragmento dos Annales. Aí encontramos, igualmente, a solução para duas dificuldades. A primeira é a variante de Sebastião Toscano em relação ao vers. 846 da Eneida - variante em que aparece a mais a palavra «homo», a menos o vocábulo "qui» e «restituit» em vez de «restitues». A segunda dificuldade era o acrescento «Non ponebat enim rumores ante salutem», que não figura no lugar citado de Virgílio. Mas vamos ao texto:

Unus homo nobis cunctando restituit rem.

Noenum rumores ponebat ante salutem; ergo postque magisque viri nunc gloria claret.

Annales, XII, 360-362. (Utilizamos Remains of Old Latin, newly edited and translated by E. H. WARMington, I, Cambridge, Massachusetts - London 1961, p. 132).

Relativamente à nova variante com que agora deparamos de «Noenum rumores ponebat ante salutem», em vez de «Non ponebat enim rumores ante salutem», aduzido por Mestre Toscano, diremos que o «noenum» (forma arcaica de «non enim») é uma emenda de Lachmann a Luc. III, 194. Os códices trazem, porém, «non enim», que foi mantido por Baehrens (Fragmenta poetarum Romanorum). L. Müller (ed. e Einleitung - Quintus Ennius) sugere «non enim». Cf. Q. ENNo, I Framenti delli Annali (in "Collezione di classici greci e latini»), Turim 1956, p. 79.

Como é evidente, Sebastião Toscano não pôde aproveitar-se, no século XVI, destes progressos da investigação e da crítica textual modernas. Não teve à mão, sequer, a obra de Énio, tal qual podemos hoje dispor dela, por ser também recente a recolha e compilação dos restos dessa obra que chegaram até nós. Há-de ter buscado os versos nalgum florilégio. Mas é interessante notar que o seu texto respeita fielmente a estrutura métrica do hexâmetro dactílico - Nōn pō/nēbăt è/nim // rū/mōrēs / āntě sã/lūtếm - ao passo que na outra variante tropeçamos no sexto pé - băt, breve, por estar seguido de vogal - quando o velso exige que se conte como longo. Uma liberdade admissível, especialmente em Énio, poeta arcaico como foi.

(66) A margem tem: Magnânimo.

(67) Cf. nota 52. (A margem tem: Ethica 4). 
Nesta virtude se mostrou Afonso de Albuquerque. Porque havendo em seu tempo na Índia (sendo ele capitão geral e governador) muita gente revoltosa, assi grande como pequena, a do mar e a da terra, capitães, fidalgos, soldados, pilotos, mestres e marinheiros, que parecia que os homens $e$ as strelas stavam conjurados contra ele (quando ele melhor o fazia, como convinha ao serviço de seu rei e senhor), vindo-lhe cada dia com treições e novas invenções, tudo com sua prudência e grande ânimo vencia e sofria, atalhando a muitas desordens de gente inquieta e desmandada.

Em combater os Mouros, como não venceu ao grande Cipião Africano? Mais fez, sem dúvida, em os sujeitar ao nosso cristianíssimo rei de Portugal, que Cipião, aos Romanos. Porque Cipião os combateu por terra, bárbaros que em suas terras deixava pacificos, mas Afonso de [fol. 10v] Albuquerque os combateu por mar e por terra (quatro mil léguas de sua pátria, onde não tinha outro socorro senão o de Deus), e a gente que em sua terra e na alheia dominava, sendo mui práticos e exercitados na guerra, vencendo-os e lançando-os do domínio que tinham, com muito vitupério, perdendo o crédito que na terra alheia tinham ganhado, com tanta honra e glória nossa, quanta ganhou nesta conquista, como largamente se vê em suas crónicas. Bem podemos dizer dele o que diz Virgílio do grande Fábio: Tu maximus ille es. «Tu és aquele maior de quantos capitães houve no mundo» (68).

As três fortalezas que fez foram o castelo de Cochim, a fortaleza de Cananor e a de Calicute. $O$ grande Cipião! $O$ grande Fábio! $\delta$ grande Eneias! Quem contará tuas grandezas? Direi de ti o que Horácio disse de Agripa:

Scriberis Vario fortis, et hostium

Victor, Maeonii carminis aliti,

Quam rem cumque ferox navibus, aut equis

Miles, te duce, gesserit.

Nos, Alfonse, nec haec dicere, nec gravem

Pelidae stomachum cedere nescii,

$\mathrm{Nec}$ cursus duplicis per mare Ulyssei,

$\mathrm{Nec}$ saevam Pelopis domum,

Conamur, tenues grandia: dum pudor,

(68) À margem tem: Eneida 6. 
[fol. 11] Imbellisque lyrae Musa potens vetat

Laudes egregii Caesaris, et tuas,

Culpa deterere ingenii (69).

$\mathrm{O}$ terque quaterque beate, mi magne Alfonse (70)! $\mathrm{O} \mathrm{mi}$ magne Trimegiste (71)! $\delta$ três e quatro vezes bem-aventurado! $\delta$ meu grande Trismegisto Afonso!

Mercúrio, neto do grande Mercúrio, cujo avô foi Atlante, astrólogo, que florece no tempo que Mousés naceu em Egito, por ser em três cousas estremado - grão Príncipe, grão Filósofo e grande Sacerdote -, chamaram-lhe os Gregos Trismegisto, que, em nossa lingua, quer dizer três vezes grandíssimo (72). Como não chamaremos nós ao nosso grande fidalgo, grande capitão e grande governador Afonso de Albuquerque Trismegisto, e sete vezes bem-aventurado, sendo ele em real alteza tantas vezes três e nas quatro cardeais virtudes tão estremado (73)? Chamo-lhe

(69) Horácio, Ode V (liber I), 1-12, com a única diferença de "Agrippa» ter sido substituído por "Alfonse». A métrica foi respeitada nessa substituição. $O$ verso é um asclepiadeu menor ou coriambo (conforme a maneira de medir). A margem tem: Oratio ad Agrippam. Ode 6.

(70) Acomodação de Virgílio:

Extemplo Aeneae soluontur frigore membra; ingemit et duplicis tendens ad sidera palmas talia uoce refert: "O terque quaterque beati, quis ante ora patrum Troiae sub moenibus altis contigit oppetere!...»

Eneida, I, 92-96.

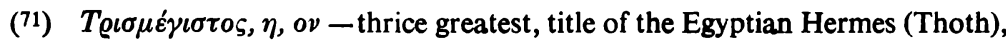
CPHerm. 125 ii8 (iii A.D.), OGI 716 (Achmim, iii A.D.), Ph. Bybl. ap. Eus. PE I. 10,

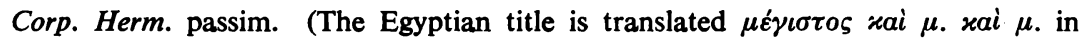
Wilchen Chr. 109. 6 (iii B.C.)). LIDDEL and ScoTt, A Greek-English Lexicon.

(72) Para esclarecer melhor este passo, cf.: ARMANDo DE Jesus Marques, Hermes Trismegisto en dos escritores portugueses del Quinientos: Fr. Sebastián Toscano y Fr. Héctor Pinto, in «La Ciudad de Dios», CLXXXIX (1976), pp. 283-284.

(73) Renunciemos a sorrir e abstraamos, por uns momentos, das nossas concepç̃os actuais, antes de pensarmos ter-se deixado arrastar Frei Sebastião Toscano por um jogo de números (o três e o quatro, somando sete), sem nada de original nem miga de bom gosto. E para isso recorramos a HENRI DE LUBAC, Exégése Médiévale, 2. P. te, Paris 1964, aproveitando o cap. VII da dita obra (I - «Symboles numériques», pp. 7-40).

Durante muito tempo, os melhores espíritos consideraram o simbolismo dos números como tudo o que há de mais sério. Longe de tratarem o assunto fantasiosa- 
eu Trismegisto, e se outro nome há maior, que a tão excelente capitão se deva, isso lhe chamo.

mente, colhiam dele algo que conferia à sua visão do mundo a marca da verdadeira objectividade, para além de um certo carácter estético. $\mathrm{O}$ número, com as suas regras imutáveis, ligava todos os elementos, introduzia neles a ordem, a disciplina, o que Boécio chama o «temperamentum», isto é, a conexão precisa de todas as coisas na harmonia universal.

As tradições numéricas bebidas por Frei Sebastião Toscano nos Padres da Igreja remontam à mais alta antiguidade. Muitas foram comuns aos Semitas e aos Gregos. O simbolismo dos números está presente no Antigo Testamento e encontramo-lo igualmente no Evangelho. Quanto à metafísica deste simbolismo, herdaram-na principalmente das tradições pitagóricas, largamente difundidas no ambiente greco-romano por obras tais como o De principiis numerorum, de Varrão, e a Introdução aritmética de Nicómaco de Gerasa, traduzida para latim por Apuleio. A especulação sobre os números é considerada por todos, exegetas e filósofos, como muito importante. Vários vêem nela o primeiro degrau da contemplação. Em razão deste «mistério dos números» a aritmética foi considerada indispensável à teologia. E estas concepções dominaram toda a Idade Média.

Dito isto, a modos de introdução, tratemos agora do que vem mais ao caso, continuando com o P. de Lubac (ou melhor, com os Santos Padres e os outros autores medievais em que se estriba).

O número, diz Santo Isidoro de Sevilha, è a «congregatio unitatis, vel ab uno progrediens multitudo». De acordo com esta definição, a unidade não é um número: «non tam numerus, quam principium, fons et origo omnium numerorum».

Por uma razão inversa, o dois não é um número verdadeiro. É um composto, se lhe podemos chamar assim, "sem meio e sem ligame», que não possui nenhum princípio de unidade. Dois significa dualidade, conflito insolúvel; é uma ruptura, uma oposição, um escândalo; é o resultado da fissura que destrói a unidade. E se é certo que o número binário significa algumas vezes o duplo mandamento da caridade, a razão é que este mandamento é, simultâneamente, duplo e uno.

Entre todos os números sagrados, há alguns que na Escritura e no simbolismo cristão têm um lugar eminentemente privilegiado. Assim, três é o primeiro número verdadeiro, por ser o primeiro número organizado, comportando princípio, meio e fim, unidos num todo, numa igualdade perfeita.

Relativamente ao número quatro, enquanto que a unidade dá o ponto, o dois a linha e o três a superfície, o quatro acrescenta-lhe o volume, que corresponde ao sólido. Uma pedra de lados iguais - lapis quadrus, lapis quadratus - onde quer que seja lançada, qualquer que seja o lado sobre que tombe, fixa-se sempre numa posição estável. É este número que divide a existência do homem em quatro idades: infância, adolescência, juventude, maturidade. Por analogia, estende-se às virtudes da alma porque, à imagem do "quadratum solidum», a consciência do justo pode chamar-se «quasi quadrata conscientia» tendo por lados as quatro virtudes cardiais.

Três e quatro são, pois, a transcendência e a imanência. Deus e o homem, ou Deus e o universo. Constituem ainda o eterno e o temporal. São a forma do 
Tinha Afonso de Albuquerque uma grande virtude cristã (74), que é vingar-se dos imigos, não com injúrias, mas com honras e benefícios. Da qual virtude deu ele grande exemplo e singular mostra na morte de um seu imigo. $O$ qual, sendo o autor de todas ou das mais das murmurações e embrulhadas [fol. 11v] que os maus faziam contra ele, morrendo este seu imigo em Cochim, só e desamparado de seus amigos (se, porventura, entre maus pode haver amizade), sabendo-o o bom governador $e$ cristão capitão, vestiu-se um capuz e foi assi, acompanhado dos seus, vestidos de negro, acompanhar aquela última e final honra que se faz aos defuntos, pagando-lhe as exéquias e gastos que se fezeram polo defunto.

Deste feito piedoso, deu ele a rezão aos que de tal cousa se espantaram, dizendo: - Não me hei-de alembrar das próprias injúrias, mas de quão bem ele o fez na tomada de Ormuz, onde me ajudou, pelejando como bom cavaleiro.

Muito havia neste feito que contar, se o tempo e o lugar o consentira. Mas não quero por agora que noteis outra cousa, senão, como este defunto achou na vida muitos que o acompanhavam a mal viver, e na morte não achou um daqueles, que o ajudasse a bem morrer. Tarde ou nunca será bom companheiro na morte o que foi mau na vida. Tomemos, pera nossa vida, os desenganos que nos dá a morte alheia.

Tinha mais o nosso grande capitão aquela disposição de ânimo que se requere no Príncipe, como o pinta Homero, grande poeta heróico dos Gregos, no segundo livro da Ilíada (75), dizendo que [fol. 12] na polícia bem ordenada, não há-de haver muitos que mandem, mas um só rei, um

espírito e a da matéria organizada. A diferença destes dois números é a das duas zonas do ser, irredutíveis. Simplesmente, se estas duas zonas devem permanecer para sempre distintas e se a sua fronteira é completamente intransponível, elas não estão, todavia, separadas. O Criador penetra a sua criação. Deus faz o homem à sua imagem. Mais, o Verbo de Deus incarna e o tempo humano transforma-se em história divina. Por conseguinte, três e quatro unem-se e compenetram-se sem deixar de se distinguir.

Da soma de três e quatro (tal qual a faz Frei Sebastião Toscano), surge o número sete. Este lembra ao cristão o número do Espírito septiforme prometido na profecia de Isaías e que encerra toda a história da salvação. Também o livro do Apocalipse está, todo ele, urdido de septenários. O dia da celebração da Páscoa foi escolhido, diz ainda Santo Agostinho, em relação com a sua perfeição mística. Numa palavra: o sétimo dia é o grande Dia do repouso do Senhor após a sua criação, o começo do grande sábado eterno.

(74) A margem tem: Virtude cristã.

(75) A margem tem: Homero, Ilíada 2. 
só senhor e governador, e esse, posto da mão de Deus. E que esse há-de ser virtuoso, mantedor da justiça e que tenha cuidado dos seus. Porque pera isto é posto de Deus: não pera si, mas pera eles. As palavras de Homero são as que se seguem:

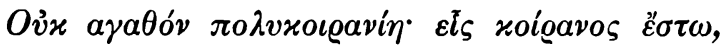

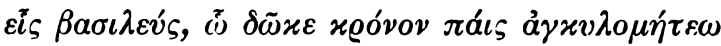

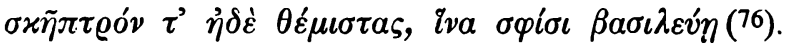

Esta doutrina louva muito Dion Crisóstomo (77), orador e filósofo, dizendo que o príncipe há-de ser muito amigo de Deus e dele confiado. A qual confiança procede da graça divina e de nossas boas obras. Porque de outra maneira, se nós, vivendo mal, speramos e confiamos em Deus, tendo tal vida, mais se poderia chamar a tal confiança blasfémia, que sperança (78). Porque mal sente de Deus o que cuida que ele ama os

(76) Iliada, II, 204-206 (Texte établi et traduit par Paul Mazon, avec la cola-

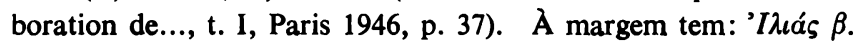

(77) A figura talvez mais representativa da renovação do cinismo no séc. I foi Díon Crisóstomo (40-117?), natural de Prusa, na Bitínia, de família nobre e rica. Primeiro, dedicou-se à retórica tendo-se afirmado como um bom orador. No ano 82, foi desterrado por Domiciano, do mesmo passo que lhe eram confiscados os bens. Andou errante durante doze anos, pobre e doente. Após uma crise moral, dedicou-se à Filosofia, buscando nela uma norma de vida que julgou encontrar, por fim, em Sócrates, em Platão, nos estóicos e, sobretudo, nos cínicos. Tomou por modelos a Diógenes e Heracles, dedicando-se à oratória popular. Após a morte de Domiciano, foi-lhe levantado o desterro e recuperou os seus bens. Enviado a Roma como embaixador, pronunciou, diante de Trajano, o seu discurso primeiro sobre o reino. Na sua última época, dedicou-se principalmente à oratória política, considerando a monarquia como a forma mais perfeita de governo, pois imita o governo dos deuses sobre o mundo. Conservam-se alguns dos seus oitenta Discursos, só havendo referências aos seus Diálogos e Exortações.

Cf. Guillermo Fraile, O.P., Historia de la Filosofía, I, Madrid 1956, pp. 238 e 634-635. (A margem tem: Dion Philosophus).

(78) «Dicamus ergo de rege, qui et iuxta Homerum, ipsamque veritatem rex sit. Hic enim sermo simpliciter habitus, absque omni adulatione aut convicio, ipse per se optimo similem notum facit, laudatque, quatenus illi similis est: dissimilem autem redarguit, atque vituperat. Est ergo primum deorum studiosus, et divinitatis cultor. Neque enim fieri potest, ut vir bonus et iustus ulli magis fidat quam iustissimis atque optimis diis. Quicunque autem, quum malus sit, se diis placere putat, eo ipso primum iam pius non est. Aut enim fatuam, aut pravam statuit esse divinitatemy. - De regno, Oratio prima, - Dionis Chrysostomi, praestantissimi et philosophi et oratoris, Orationes octoginta, in latinum conversae... Thoma Naogeorgo Straubigensi interprete. Basileae [1552], per Ioannem Oporinum, p. 2. 
maus com sua má vida, como a Scriptura Santa diga que Deus quer mal ao mau e à sua maldade (79).

$O$ segundo que deve ter o príncipe é reger com justiça, amando os homens sobre todos os outros homens. Como vemos que os que tem cuidado de governar alguns animais, amam mais aqueles de que se encarregain sobre todos os da outra spécie. $O$ caçador tem mais cuidado dos cães [fol. 12v] que das ovelhas: e eles que o defendem e o amam mais que aos outros homens. O pastor de ovelhas tem mais cuidado delas que do outro gado: e elas que conhecem sua voz e o seguem. O que guarda touros e vacas, busca-lhes pastos convenientes, sendo-lhes mais afeiçoado que às ovelhas: e eles, por mais feros que sejam, stranhando todo outro género de homens, aos quais se enviam, reconhecem o seu pastor e, na sua vista, depõem sua natural fúria (80).

Desta maneira, o que apascenta homens e os tem a seu cárrego e regimento, há-os de amar, reger, e apascentar, e fazer-lhes mercês, amando-os mais que a todos os outros homens.

Trazem os reis, príncipes e senhores estas obrigações insertas $e$ engastoadas em seu nome, porque são chamados na lingua grega Anactes, de "ákos», que quer dizer mezinha, porque hão-de curar seus súbditos, como o diz Plutarco e Eustátio (81).

(79) Sap. 14, 9: «Similiter autem odio sunt Deo impius et impietas eius». (A margem tem: Sap. 14).

(80) Ao compor esta bela tirada, Toscano pode ter-se servido do livro $3 .^{\circ}$ das Geórgicas, já que este apresenta uma longa série de conselhos sobre os cuidados a ter com as diferentes espécies de gado: cuidados nos estábulos, na procura dos pastos, etc..

Todavia, é ineludível a influência literária de alguns textos de S. João: «Huic ostiarius aperit, et oves vocem eius audiunt, et proprias oves vocat nominatim, et educit eas. Et cum proprias oves emiserit, ante eas vadit: et oves illum sequuntur, quia sciunt vocem eius» (Ioan. 10, 3-4); "Omnes quotquot venerunt, fures sunt, et latrones, et non audierunt eos oves» $(10,8)$; «Ego sum pastor bonus: et cognosco meas, et cognoscunt me meae» $(10,14)$.

Este hibridismo, a ser real, não nos deve espantar. Já a renascença carolíngia se havia colocado, de alguma maneira, sob o signo de Virgílio. E, após a derrocada do Império, as vicissitudes políticas não secaram jámais, no seio da Igreja latina, o cuidado das letras, sendo numerosos os que queriam, por vezes até ao excesso, "cum evangeliis bucolica meditari» (cf. HENRI DE LUBAC, Exégèse médiévale, I-I, Paris 1959, p. 73).

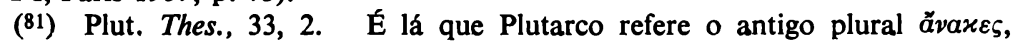

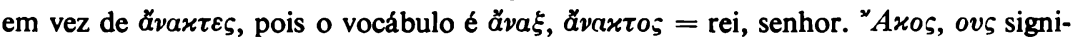
fica, de facto, remédio. Mas transcrevamos o texto:

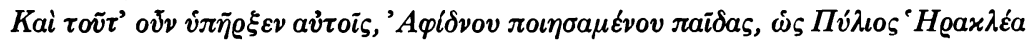

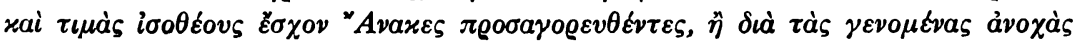


Todas estas virtudes resplandeciam no nosso grande capitão Afonso de Albuquerque, que toda sua confiança punha no Senhor. A Ele pedia socorro do Céu quando dava algũa batalha ou havia de fazer algũa cousa, dizendo aos seus que não temessem, porque sua era a vitoria, que assi o sperava ele nas cinco chagas e paixão de Nosso Senhor Jesu Cristo, de que ele era muito devoto. E como ele sperava, [fol. 13] assi o via, sendo divinalmente consolado e visivelmente muitas vezes do Céu visitado com milagres e maravilhas.

Onde ũa vez, indo de Camarão para Judá, dentro no streito de Meca, stando sua frota surta com muitos enfadamentos que traz o caminhar (e mais por mar), o consolou o Senhor, e a todos os seus, com ũa cruz que lhes apareceu no céu, contra a terra do Preste João, mui crara e mui resplandecente. Pola qual como passasse ũa nuve, partiu-se em muitas partes, sem tocar na cruz, nem lhe cobrir nada de sua craridade. O qual milagre vendo toda a gente da frota, pôs-se de joelhos e adorou a cruz com muitas lágrimas.

Quando tomou a Goa, entrando nela se achou nos liceces de ũa parede um crucifixo de cobre, que têm em muita veneração naquela cidade (82).

Também os santos o favoreciam, os quais ele invocava e chamava em sua ajuda. Como se viu visivelmente Sant'Iago pelejar em seu favor

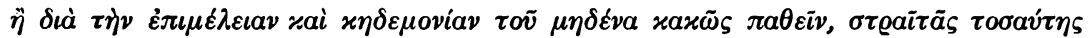

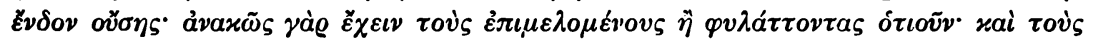

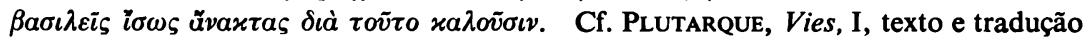
de R. Flacelière, E. Chambry e M. Juneaux, Paris («Les Belles-Lettres») 1964, p. 43.

Quanto a Eustátio, bispo de Tessalónica e comentador de Homero (séc. XII), descobrimos duas referências:

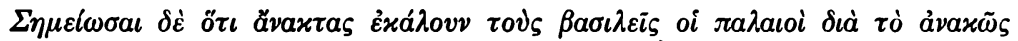

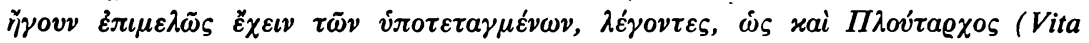

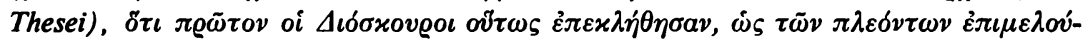

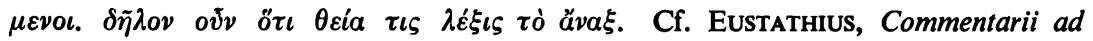
Homeri Iliadem, I, Hildesheim (Georg Olms Verlagsbuchhandlung) 1960, p. 19. É o comentário ao verso A (= Canto I da Ilíada) 7.

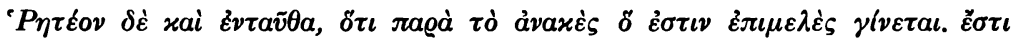

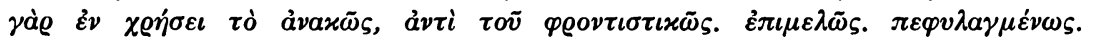
Cf. Eustathius, Commentarii ad Homeri Odysseam, I, Hildesheim (Georg Olms Verlagsbuchhandlung) 1960 , p. 71 . É o comentário ao verso $\alpha$ (= Canto I da Odisseia) 399.

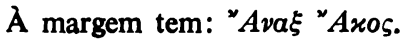

(82) A margem tem: Crucifixo. 
nas batalhas. Daqui vieram seus felices sucessos, suas vitórias e triunfos, por ter a Deus e aos santos de sua banda, como o diz o invictíssimo capitão, rei e profeta David: Qui confidunt in Domino, sicut mons Sion; non commovebitur in aeternum, qui habitat in Hierusalem (83). «Os que confiam no Senhor serão fortes e confiantes, como o monte de Sião; [fol. 13v] não se moverá jamais o que mora em Jerusalém».

Teve também este bom capitão a virtude da justiça, tão encomendada e necessária aos príncipes, porque foi barão mui justo (84).

Grande argumento e mostra deu desta virtude quando, na tomada de Malaca, disse à mulher de Utematuraja, grão senhor e grande rico, que os Portugueses não vendiam a justiça por dinheiro (85). Ai, Deus, assi seja sempre e assi façam todos como o bom capitão e dezia e fazia!

Isto disse ele àquela dona porque, tendo seu marido, e um seu filho, e um neto, e um genro condenados a degolar por justiça, ofrecendo-lhe ela vinte e oito quintais de ouro, por que lhes perdoasse, nunca pôde acabar com o justo governador que os não mandasse degolar, porque o mereciam.

$\delta$ quantos capitães, justiças e juizes houvera, que lhes riram e creceram os olhos com tão crecido monte de ouro enganoso! E pera capa desta cobiça se ofresceram guerras e obras pias, com outras seiscentas não sei que necessidades em que gastá-lo, não havendo outra necessidade algũa, senão o justo juíz e sua verdade.

Foi este bom governador tão justo que, hoje em dia, os gentios, quando lhes não fazem justiça, vão à sua sepultura ofrecer-lhe boninas $e$ outros dões. E o chamam e invocam, que lhes faça jus-[fol. 14]tiça. Porque eles não crêem que o bom capitão é morto. E assi o deziam, quando o levavam a enterrar: que ele não morrera, mas que o mandara Deus chamar, por ter dele necessidade pera algũa guerra, segundo a gentilidade das gentes bárbaras e ignorantes.

Teve a outra virtude dos príncipes e dos que governam, que é ser amigos dos seus, fazer-lhes mercês e dar-lhes mezinha pera seus males. Ó como provia as suas necessidades! Era pés dos mancos, olhos dos que não viam, misericordioso a todos os míseros (86).

(83) Ps. 124, 1-2.

(84) Ȧ margem tem: Justiça.

(85) A margem tem: Utematuraja.

(86) 1 Cor. 9, 19-22: «Nam cum liber essem ex omnibus, omnium me servum feci, ut plures lucrifacerem. Et factus sum Iudaeis tanquam Iudaeus, ut Iudaeos lucrarer: iis qui sub lege sunt, quasi sub lege essem (cum ipse non essem sub lege) 
Onde me levas, bom capitão, que não são cronista? Não quero dizer como viveste (a quem o viver estava mui bem), nem menos como pelejaste, e o bárbaro hemisfério com o nosso ajuntaste, o um $e$ o outro polo uniste, e o Oriente ao nosso Ocidente trouxeste, e tudo ao teu rei e senhor sujeitaste. Cantem os poetas gregos $e$ os latinos tuas vitórias: os heróicos, tuas ensangrentadas batalhas, $e$ os líricos, tuas virtudes! $E u$, como morto, chorarei a tua morte e, como pobre, me enriquecerei das grandes e muitas riquezas de tuas virtudes que, nela, com exemplos, a todo o mundo deixaste.

Chegada a hora da morte (antes, da vida, que «o morrer ao cristâo é ganho» (87)), em que o bom capitão havia [fol. 14v] de descansar de seus muitos, grandes e honrosos trabalhos da guerra da terra e do mar que a gente bárbara fazia à custa de seu proprio sangue (que suas roupas muitas vezes tingia, porque ele nos mais fortes encontros se achava), querendo-o apousentar o seu Rei e Senhor na glória, empadroar no reino da gente viva, mandou-o chamar por ũa enfermidade corporal. Ele, sentindo que daquela jornada partiria da terra ao Céu, estando em Ormuz (onde aquela enfermidade o tomou) edificando ũa fortaleza, mandou chamar a todos os capitães que ali estavam e fez-lhes ũa prática mui douta (porque ele era latino, sábio, discreto e bem falado), a qual prática os provocou a muitas lágrimas, rogando-lhes que todos lhe dessem suas menages de obedecer àquela pessoa que ele encomendasse seus poderes, até que de Portugal viesse provisão.

Eles lhe responderam, com muitas lágrimas, que Deus lhe daria saúde e que, quanto ao mais, eles eram contentes de estar polo que ele ordenasse. $O$ que ele lhes agradeceu muito. E chamou logo a Pedro de Albuquerque, seu sobrinho, dizendo que, por ele ser tal pessoa com quem a gente folgaria de ficar naquela fortaleza, merecendo-o ele por sua cavalaria e fidalguia e por outros respeitos, lhe fazia mercê daquela forta-[fol. 15]leza em nome del rei D. Manuel, seu senhor. E que, dali por diante, tivesse cuidado

ut eos qui sub lege erant, lucrifacerem: iis qui sine lege erant, tanquam sine lege essem (cum sine lege Dei non essem: sed in lege essem Christi) ut lucrifacerem eos qui sine lege erant. Factus sum infirmis infirmus, ut infirmos lucrifacerem. Omnibus omnia factus sum, ut omnes facerem salvos». Também terá tido presente, dado o paralelismo da frase, $M t$. 11, 5: «Caeci vident, claudi ambulant, leprosi mundantur, surdi audiunt, mortui resurgunt, pauperes evangelizantur».

(87) Phil. 1, 21: «Mihi enim vivere Christus est, et mori lucrum». À margem tem: (Morte de Afonso de Albuquerque). 
dela, porque ele não tinha disposição pera entender em outra coisa senão na conta que tinha de dar a Deus dos desserviços que lhe tinha feitos. E que pusesse nome à fortaleza, Nossa Senhora da Conceição.

Isto feito, fez todos os autos cristãos, confessando-se e tomando o Santíssimo Sacramento da Eucaristia, feito testamento, e logo se partiu de Ormuz para a Índia, por deixar suas cousas concertadas e levar sua alma em paz ao Céu, deixando depositado seu corpo em Goa, em sua capela, que ele fezera, por nome chamada Santa Maria da Conceição. Donde cle mandou que lhe trouxessem seus ossos a Portugal e os enterrassem em Santa Maria da Graça, onde agora repousa. Porque, como diz o profeta David, cumpre Deus os bons desejos de seus servos (88).

Stando ele muito propinco à morte, screveu a el-Rei ũa carta, em que dizia que fezesse Sua Alteza grande a um seu filho que em Portugal tinha, porque seus serviços o mereciam; e que, quanto às cousas da Índia, ela falaria por si e por ele ( $\left.{ }^{89}\right)$.

Lendo eu esta carta, alembrei-me de um epitáfio de Pico Mirandulano, que li na cidade de Florência (que é em Itália, no reino de Toscana), em o moesteiro de S. Domingos, scripto em ũa pedra do [fol. 15v] sepulcro, que diz assi:

Picus iacet hic Mirandula. Caetera norunt

Tagus et Ganges, forsitan et Antipodes (90).

Quer dizer: Aqui jaz enterrado Pico Mirandulano. $O$ demais - quem foi e o que fez - sabe-o o Tejo e o Ganges, scilicet, o Oriente e o Ocidente, e os Antípodas, lá o outro mundo debaixo deste (se o há) (91). Que é tanto como dizer: são tão manifestas e excelentes suas obras, que não se podem sconder ao mundo onde há gente.

Com este epitáfio de Pico Mirândola se pudera em algũa maneira satisfazer a história de Afonso de Albuquerque, porque este é o maior epitáfio em sua maneira e que melhor, sem nada contar, conta os louvores

(88) Ps. 20, 3: «Desiderium cordis eius tribuisti ei, et voluntate labiorum eius non fraudasti eum». ( $\AA$ margem tem, erradamente: Ps. 120).

(89) À margem tem: Carta pera el-Rei.

(90) A margem tem: Epitáfio.

(91) Para a explicação desta oração condicional - «se o há», cf.: ARMANDo De Jesus Marques, $O$ epitáfio de Pico della Mirandola num clássico português - De um actual problema antropologico que sugere, in "Panorama", 4. ${ }^{2}$ Série, n. ${ }^{\circ} 45$ (Março de 1973), pp. 12-16. 
de Pico, que se dele dissera por miúdo muitas cousas. Porventura, satisfazera eu desta maneira melhor a muitos, se dissera: Esta pompa, esta última honra e exéquias tão honradas, que celebramos, são de Afonso de Albuquerque. $O$ mais sabe-o o Tejo e o Ganges e, porventura, os Antipodes.

Navegando (por que tornemos à história donde nos partimos) (92) o bom capitão pera Goa, assi doente à morte, chegou sobre a barra daquela cidade. E como lhe disseram que estavam naquele porto, onde ele desejava chegar, alçou as mãos e os olhos ao céu, dando muitas gra[fol. 16]ças a Deus polo haver trazido àquele lugar, onde eram seus desejos depositar seu corpo, na capela que ganhara aos Mouros, mandando no testamento que levassem a Portugal seus ossos. Cumpriu o Senhor seus desejos, como cumpre o de seus servos (93). Porque, vindo os seus ossos na nau São Vicente e na nau Nova, chegaram aqui a salvamento (havendo passado polo mar muito perigo), como quem trazia ũas santas relíquias. E a companhia ainda não acabou de chegar. Trazê-la-á Deus com bem.

Estando ali naquela barra sobre as amarras o nosso bom governador (que tinha as âncoras de suas grandes speranças no Céu, aferradas na firme pedra, Cristo Jesu (94), seu verdadeiro Senhor e Redentor), mandou à cidade por dous médicos: um corporal, que foi Mestre Afonso, e outro da alma, que era frei Domingos, seu confessor.

Com este confessor e com Pedro de Alpoim, secretário da Índia, seu testamenteiro, esteve só aquela noite, abraçado com um crucifixo, $e$, falundo com ele, disse ao padre frei Domingos que lhe rezasse a paixão de Nosso Senhor Jesu Cristo, de que ele sempre fora muito devoto, porque nela e na cruz que consigo tinha abraçada. levava a principal sperança de sua salvação. $\delta$ santas esperanças! $\delta$ copioso resgate da pobre gente dos filhos de Adão, na qual este bom servo do Senhor e fiel até à morte cava-[fol. 16v]leiro cristão sperava(95)!

(92) Este inciso, com que restabelece o nexo da narração, foi bebê-lo a Horácio: «Illuc, unde abii, redeo» (Sátira I, 1, 108). Aliás, Toscano repete este expediente literário por mais três vezes: «Sed, ut revertamur unde sumus digressi,...» (Commentarii in Ionam Prophetam, prólogo); «Sed nos ad historiam redeamus» (Ibid., f. 18); «Muito vai, por que tornemos donde partimos,...» (Mystica Theologia, f. 36v).

(93) Cf. nota 88.

(94) Cf. nota 38 .

(95) Mt. 25, 21: «... Euge serve bone, et fidelis (...) intra in gaudium domini tui». 
Com estes dous seus amigos, scilicet, o confessor e Pedro de Alpoim, seu testamenteiro, steve toda a noite departindo. Não como quem morria. Mas mui quieto e descansado, como quem parte de um reino a outro, despondo de sua casa e bens. Qual é a morte dos justos, como foi a do patriarca Jacob, do qual diz Mousés, no livro da criação do mundo, que chamam Génesis: que, stando pera se partir desta vida, lançou a bênção a seus filhos, profetizando o que deles havia de ser, e lhes encomendou que o enterrassem e levassem a sua terra a descansar na morte, pois não descansara na vida, dizendo - Eu me vou ajuntar a meu povo; enterrai-me com meus avós na sepultura que está no campo de Efron, heteu, contra Mambre, na terra de Canaan, a qual comprou Abraão, com o campo em que ela está, a Efron, heteu, pera possissão de sepultura. Ali, está ele enterrado com sua mulher Sara, e Isaac, com Rebeca e Lia.

Acabado de instruir os seus, ajuntou os pés sobre a cama e spirou, e foi ajuntado a seu povo (96).

Muitas e grandes cousas havia aqui que contar, que calo pola brevidade do tempo. Mas ao menos de ũa queria que não fôsseis squecidos. Esta é, que, sendo tanto sem cuidado os santos de casas grandes e ricos paços, contentes com ũas pequenas, pobres e frias [fol. 17] cabanas ou tendas, conhecendo (como deles diz São Paulo) ser peregrinos sobre a terra (97), não tendo conta com fazer casa nem comprá-la, eram mui cuidadosos das sepulturas. E pera isto compravam campos em que as faziam e lavravam (98), mui solicitos da ossada os que a carne pisaram e acoucearam, mortificando-a com os jejuns e cilício, mandando a seus filhos que a levassem a sua terra (como o mandou José a seus irmãos, dizendo: Levai convosco meus ossos deste lugar (99)), não tendo conta com a carne vivendo em terras alheias.

Isto faziam porque tinham a fé da ressurreição, fazendo sepulturas, como arcas de deposito em que guardavam as tais relíquias que haviam ainda de ter honra perpétua, como gente que tinha seu nome scripto no

(96) Gen. 49, 1-32. (A margem tem: Gen. 49. Efron.).

(97) Hebr. 11, 13: «Iuxta fidem defuncti sunt omnes isti, non acceptis repromissionibus, sed a longe eas aspicientes, et salutantes, et confitentes quia peregrini et hospites sunt super terram». (齐 margem tem: Haeb. 11).

(98) Cf. Gen. 49, 30.

(99) Gen. 50, 24-25: «Cumque adiurasset eos atque dixisset: Deus visitabit vos, asportate ossa mea vobiscum de loco isto: mortuus est...» ( $\AA$ margem tem: Gen. 50). 
livro da vida (100), na sua terra verdadeira dos vivos, onde todo seu bem stava. Como, polo contrairo, se diz dos maus que puseram e empadroaram seu nome em suas terras, como diz deles o profeta David no psalmo: Vocaverunt nomina sua in terris suis (101).

$O$ segundo que se deve considerar é ver como morrem os santos pacífica e quietamente, falando, partindo-se e despondo de suas cousas, não como quem morre, mas como quem vai de ũa terra a outra pera tornar a ver os seus.

$O$ terceiro que pedem estas palavras do patriarca [fol. 17v] é ver que povo é este pera onde partiram os santos passados, pois não era o paraíso terreal, que ainda não estava aberta a porta do Céu.

Serem ajuntados os santos daquele tempo a seu povo, há-se entender quanto à alma, pois isto se fazia antes de enterrar o corpo. Alguns doutores dizem que este povo dos santos antigos era o ajuntamento ou frequência dos anjos. Outros dizem que era o Limbo, onde os santos padres estavam.

A esta partida dos santos patriarcas foi muito semelhante a de Afonso de Albuquerque, que partiu desta, que chamam, vida, falando e despondo de sua alma e corpo com a fé santa e católica da ressurreição, na qual outra vez seu corpo e alma se unirão e ajuntarão, pera entrar no reino eterno, com o seu Rei e Senhor Jesu Cristo, no seu reino da glória do Paraiso, pola viva fé e grande confiança que nele sempre teve, acompanhada com muitas e boas obras.

Estando assi abraçado com a cruz, mandou que lhe vestissem o hábito de Sant' Iago (de que ele era comendador), pera morrer nele. Feito tudo aquilo que um bom e católico cristão convinha fazer, cerrados os braços com a cruz, e abertos os olhos e pos-[fol. 18] tos no crucifixo, deu a alma ao Senhor do mundo, ao domingo, ũa hora antes menhã. Assi acabou, antes, ressuscitou na alma da sepultura de seu corpo (que assi se chama o corpo na língua grega - $\sigma \tilde{\omega} \mu \alpha$, quase $\sigma \tilde{\eta} \mu \alpha$, que quer dizer, na nossa, sepultura (102)). E isto o dia que da fria sepultura de

(100) Principalmente Apoc. 3, 5: «Qui vicerit, sic vestietur vestimentis albis, et non delebo nomen eius de libro vitae, et confitebor nomen eius coram Patre meo, et coram angelis eius». Cf. também Phil. 4, 3: «Etiam rogo et te, germane compar, adiuva illas, quae mecum laboraverunt in Evangelio cum Clemente, et caeteris adiutoribus meis, quorum nomina sunt in libro vitae».

(101) Ps. 48, 12. (A margem tem: Ps. 48).

(102) No estilo de vida pitagórico, «el alma procede de otro mundo, se ha manchado con el pecado y ha de llevar ahora, encadenada al cuerpo, una vida de 
pedra ressuscitou o seu Senhor crucificado, de que ele era muito devoto.

Composto o corpo, que, na nau onde spirou, deixara, havendo partido a alma ao Céu, levaram-no a terra com tamanho pranto, que parecia que se fundia o rio de Goa. A gente que em terra, no cais, o sperava, com D. Guterre, capitão da cidade, com toda a fidalguia, e cavalaria, e outra gente que na terra havia, com muitos clérigos e religiosos, muitos cristãos, mouros e gentios, fez tão grande alarido, chegando o corpo a terra, que o mundo se acabava, o ar se encendia e o céu se rompia. Pranto semelhante ao que fizeram os Egípcios pola morte do patriarca José, nos tempos antigos (103).

Depois de haver encomendada a alma a Deus (que os clérigos e os religiosos com lágrimas fazer não podiam), tomaram-no os fidalgos no catle, aos ombros, e levaram-no debaixo de um pálio à sua capela de [fol. 18v] Nossa Senhora da Conceição, seguindo-o toda Goa, homens e mulheres, cristãos, mouros e gentios, com grandes choros e prantos, até que depositaram aquele rico depósito em sua capela, sobre a porta de aquela cidade, por onde ele entrou, quando a tomou aos Mouros.

Como o grande capitão havia sido liberal na vida (que se diz dele nunca haver negado cousa que, da sua fazenda, lhe fosse pedida), assi o foi na morte, que, com as relíquias de seu corpo, enriqueceu o um e outro polo: a carne ficou em Oriente, em Nossa Senhora da Conceição; $e$ os ossos estão aqui no Ocidente, nesta casa de Nossa Senhora da Graça, cuja honra última celebramos neste dia; e a alma mandou ao Céu, onde de tantos trabalhos descansa agora in pace in idipsum(104).

expiación y de peregrinación, hasta que logre verse libre del cuerpo y de la sensualidad y recobre entonces su primitiva espiritualidad. El cuerpo es el sepulcro del alma $(\sigma \tilde{\omega} \mu \alpha-\sigma \tilde{\eta} \mu \alpha) »$. Cf. JohANNES HirsChBerger, Historia de la Filosofia, I, Barcelona 21965, p. 50. «Platón llega a repetir la expresión de los pitagóricos, que designaban al cuerpo como sepulcro del alma $(\sigma \tilde{\omega} \mu \alpha-\sigma \tilde{\eta} \mu \alpha) » . \quad$ Ibid., p. 118.

Também para Plotino (Enéadas IV, 8, 3), o corpo está para a alma como uma espécie de cárcere e de tumba, sendo o mundo uma caverna e um antro. Cf. GuLlLermo Fraile, O.P., Historia de la Filosofía, I, Madrid 1956, p. 721.

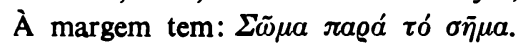

(103) Gen. 50, 10-11: «Veneruntque ad aream Atad, quae sita est trans Iordanem: ubi celebrantes exequias planctu magno atque vehementi impleverunt septem dies. Quod cum vidissent habitatores terrae Chanaan, dixerunt: Planctus magnus est iste Aegyptiis. Et idcirco vocatum est nomen loci illius, Planctus Aegypti». (A margem tem: Gen. 50).

(104) Ps. 4, 9: «In pace in idipsum dormiam, et requiescam». 
Porque não é seguro louvar os homens na vida, nem o navegante que bem navega, até que no seguro porto lance as âncoras, nem o capitão que bem peleja, até que, acabada a guerra, o não vejamos no triunfo (105), porque acontecem muitas cousas entre (como dizem) o bocado e a boca, havendo louvado em algũa maneira o pai Afonso de Albuquerque, na morte, não nos ocuparemos em louvar o filho Afonso de Albuquerque, porque ainda vive, havendo muito de que louvá-lo, por ser o au-[fol. 19]tor destas tão honradas exéquias, com sua pessoa, vindo diante do pai, a cabeça descoberta com filial acatamento e reverência, como todos vistes, acompanhado de tanta e tão ilustre fidalguia, secular e religiosa, apousentando-o em tão santa casa, que dotou com muita da sua fazenda.

Aqui, tem bem os filhos que imitar a obediência e reverência aos padres e defuntos devida. Mas, porque somos ensinados a não louvar os homens em sua vida, não diremos do vivo nada, como do defunto mui pouco dissemos, havendo muito que dizer da sua felice morte $e$ vida. Mas, porque disto estão cheias as crónicas e porque o tempo é pouco $e$ muita a calma, não direi por agora senão que, ali, naquela terra dos vivos, se transplantou o nosso branco carvalho, ali está em paz, segura de toda batalha e guerra, a nossa cândida fortaleza, a nossa santa pranta transplantada desta terra velha e cansada, naquela terra nova, onde o sol nunca trasmonta, nem lhe sucede noite, nem outra algũa mudança (106), porque sua candeia é o Cordeiro, luz do mundo, inacessível lume - lume de lume, Deus verdadeiro de Deus verdadeiro (107), perpétuo descanso da cansada gente.

Nós, que ainda cá ficamos, cansados e pobres, neste lugar de horror, espanto (108), e neste vale de lágrimas, [fol. 19v] desterrados filhos de

(105) «Nam si laudari ante gubernator non potest, quam in portum navem deduxerit, quomodo laudabis hominem, prius quam in stationem mortis successerit?» S. AmBr., De bono mortis liber unus, cap. 8, num. 35 (ML 14, 584 B). «Navis gubernator in tempestate dinoscitur, in acie miles probatur. Delicata iactatio est cum periculum non est. Conflictatio in adversis probatio est veritatis». S. CIPR., Liber de mortalitate, XII (ML 4, 612-613 A).

(106) 2 Petr. 3, 13: «Novos vero caelos, et novam terram secundum promissa ipsius expectamus, in quibus iustitia habitat». Apoc. 21, 1: «Et vidi caelum novum et terram novam. Primum enim caelum, et prima terra abiit, et mare iam non est». vero").

(107) Credo da Missa Romana: «... lumen de lumine, Deum verum de Deo

(108) Iob 10, 21-22: "Antequam vadam, et non revertar, ad terram tenebrosam, et opertam mortis caligine: terram miseriae et tenebrarum, ubi umbra mortis et nullus ordo, sed sempiternus horror inhabitat». 
Eva (109), vamos ao abrir de seu testamento, que ficou muito rico, pera nos enriquecer a todos com os tesouros de seus bons exemplos: aos reis, de bom regimento; aos príncipes, de liberalidade; aos governadores, de justiça; aos fidalgos, de virtude e fidalguia; aos cavaleiros e soldados, de ânimo e esforço; e a todos os cristãos, de religião e piedade. Finalmente, a todos enriqueceu com sua morte e vida, a todos se propôs por exemplo de bem viver, e a todos, morrendo, deixou que imitar.

A minha parte seja o Senhor a que ele serviu (110) e sua cruz de Paixão, de que ele foi devoto, sperando com ele, nesta igreja, até o dia do juizo universal. E daqui partiremos todos juntos, desta igreja, levando-o por nosso capitão - $\delta$ santo, fermoso e religioso squadrão! - e nos iremos todos apresentar no vale de Josafá (111) ao nosso Rei e Senhor Jesu Cristo, onde, ouvindo dele a final sentença - Vinde bentos de meu Padre, posseei o Reino que vos está aparelhado desde a criação do mundo. E partindo da terra, alegres, iremos cantando aquele psalmo de [fol. 20] triunfo - In exitu Israel de Egypto (112), etc.. E assi entraremos na glória, alegres, onde nos apousentaremos e empadroaremos naquele Reino eterno e glorioso.

\author{
Et sic semper cum Domino \\ erimus (113). \\ Amen!
}

\title{
LAUS DEO
}

(109) Salve Regina: «Ad te clamamus exsules filii Hevae. Ad te suspiramus gementes et flentes in hac lacrimarum valle».

(110) Ps. 15, 5: «Dominus pars haereditatis meae, et calicis mei: Tu es qui restitues haereditatem meam mihi».

(111) Nome do lugar em que Javé, segundo Joel 3, 2-14, julgará os inimigos de Israel. Os intérpretes discutem se será uma denominação alegórica ou um vale real, que deva identificar-se com o vale de Beraca (2 Par. 20, 26) ou com a torrente do Cedrón, a oriente de Jerusalém (como pretendeu uma antiquíssima opinião muito difundida entre judeus, cristãos e maometanos). As palavras de Joel não dão fundamento algum à opinião de que o juízo universal há-de ter lugar neste vale e já Cirilo de Alexandria rejeitou esta opinião como frívola e ridícula (In Ioel, 3, 2; MG 71, 389 D). Cf. Lexicon Biblicum editore Martino Hagen, S.J., II, Paris 1907, cols. 811-812.

(112) Ps. 113, 1-18.

(113) 1 Thess. 4, 16: «Deinde nos, qui vivimus, qui relinquimur, simul rapiemur cum illis in nubibus obviam Christo in aera, et sic semper cum Domino erimus». 